\title{
An Analysis of the Limited Criminal Liability Exemption in the Context of Organized
}

Crime Investigations in Canada:

$$
\text { By: }
$$

Daryl Ray Churney, B.A. (Hons.)

\begin{abstract}
A thesis submitted to the Faculty of Graduate Studies and Research in partial fulfillment of the requirements of the degree of:

Master of Arts

Department of Law
\end{abstract}

\author{
Carleton University \\ Ottawa, Ontario \\ January 2006 \\ CCopyright \\ 2006, Daryl Ray Churney
}




$\begin{array}{ll}\begin{array}{l}\text { Library and } \\ \text { Archives Canada }\end{array} & \begin{array}{l}\text { Bibliothèque et } \\ \text { Archives Canada }\end{array} \\ \begin{array}{l}\text { Published Heritage } \\ \text { Branch }\end{array} & \begin{array}{l}\text { Direction du } \\ \text { Patrimoine de l'édition }\end{array} \\ \begin{array}{l}\text { 395 Wellington Street } \\ \text { Ottawa ON K1A ON4 }\end{array} & \begin{array}{l}\text { 395, rue Wellington } \\ \text { Ottawa ON K1A ON4 } \\ \text { Canada }\end{array}\end{array}$

Your file Votre référence

ISBN: 0-494-13410-0

Ourfile Notre référence

ISBN: 0-494-13410-0

NOTICE:

The author has granted a nonexclusive license allowing Library and Archives Canada to reproduce, publish, archive, preserve, conserve, communicate to the public by telecommunication or on the Internet, loan, distribute and sell theses worldwide, for commercial or noncommercial purposes, in microform, paper, electronic and/or any other formats.

The author retains copyright ownership and moral rights in this thesis. Neither the thesis nor substantial extracts from it may be printed or otherwise reproduced without the author's permission.
AVIS:

L'auteur a accordé une licence non exclusive permettant à la Bibliothèque et Archives Canada de reproduire, publier, archiver, sauvegarder, conserver, transmettre au public par télécommunication ou par l'Internet, prêter, distribuer et vendre des thèses partout dans le monde, à des fins commerciales ou autres, sur support microforme, papier, électronique et/ou autres formats.

L'auteur conserve la propriété du droit d'auteur et des droits moraux qui protège cette thèse. $\mathrm{Ni}$ la thèse ni des extraits substantiels de celle-ci ne doivent être imprimés ou autrement reproduits sans son autorisation.
In compliance with the Canadian

Privacy Act some supporting forms may have been removed from this thesis.

While these forms may be included in the document page count, their removal does not represent any loss of content from the thesis.
Conformément à la loi canadienne sur la protection de la vie privée, quelques formulaires secondaires ont été enlevés de cette thèse.

Bien que ces formulaires aient inclus dans la pagination, il n'y aura aucun contenu manquant.

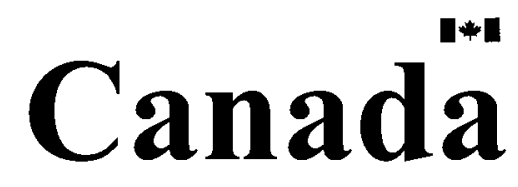




\begin{abstract}
In January 2002, the Government of Canada passed Bill C-24, adopting amendments to the Criminal Code that included a limited criminal liability exemption scheme, providing police officers with a framework in which to commit illegal acts or omissions in the course of investigations. This thesis analyzes the socio-legal conditions that surrounded the introduction of this bold policy measure and assesses the relevance and effectiveness of the limited criminal liability exemption provisions as an instrument of public policy, within the context of organized crime investigations in Canada. The paper concludes that sufficient rationale exists for the limited criminal liability exemption, however a stronger regulatory and accountability framework is required to improve the transparency of public reporting and consolidate jurisdictional approaches to undercover policing.
\end{abstract}




\section{Acknowledgements}

To Richard and Mary - my teachers, mentors and friends - whose constant support and encouragement has meant more to me than I can possibly express with words.

To Christopher - for being a brother (and police officer) that I am immeasurably proud of.

To Raymond - for being patient. 


\section{TABLE OF CONTENTS}

Chapter 1: A Unique Congruence of Socio-Legal Issues

Introduction.

Chapter 2: $\underline{\text { R. v. Campbell }}$

Toward a Limited Criminal Liability Exemption...................................10

The Facts of $\underline{R}$. v. Campbell..................................................... 11

The Supreme Court of Canada.....................................................14

Law Enforcement and Criminal Liability White Paper...........................18

Bill C-24 (Organized Crime and Law Enforcement)............................19

Chapter 3: Organized Crime in Canada

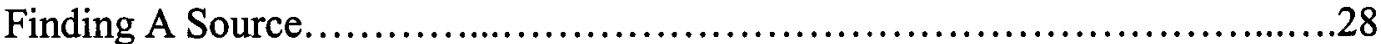

The Criminal Intelligence Service of Canada (CISC) ..........................29

Current Trends in Organized Crime in Canada...................................32

The Media and Organized Crime - Shaping Our Perceptions.......................36

Public Opinion and Organized Crime - What Do We Really Know?.....................39

Measuring Success?.................................................................................................4

Chapter 4: The Limited Criminal Liability Exemption

An Environmental Scan........................................................47

An Academic Perspective.....................................................49

Managing and Mitigating Risk - Guidelines for Undercover Work................57

What Are the Results So Far? .............................................................................65

Chapter 5: A Convergence of Issues

Multiple Dimensions, Multiple Considerations................................69

Determining Relevance and Effectiveness.....................................71

Determining Measures of Accountability .......................................75

What Is Reasonable and Proportional?................................................................76

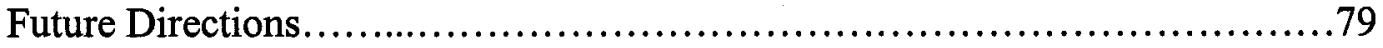

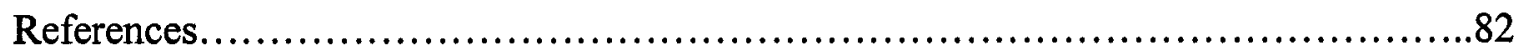




\section{Introduction}

The study of organized crime has become an area of immense interest and debate in recent years. This is due in part to both an increase in public awareness of organized crime's impact on modern life and the resulting flurry of governmental policy and legislation in response, as well as recognition among academics and governments that a truly pervasive and ill-understood social phenomenon has been and continues to be at work. As stories of organized crime continue to grab headlines in the popular media, concerted research and policy analysis are underway in academic journals and government departments in a renewed effort to better understand the dimensions and implications of this type of criminal activity.

The most important point to note at the onset of this discussion is that the central difficulty in studying organized crime in Canada, as elsewhere, is that it is an expansive topic with loosely defined borders and an ability to draw the researcher off on a host of social, political and economic tangents. On first thought, the concept of organized crime brings to mind prominent and often-repeated images of ethnic-based networks and outlaw motorcycle gangs (OMGs) whose nefarious lifestyles are increasingly exposed by print and visual media. However, such simple characterizations can no longer suffice in the face of mounting evidence that organized crime is fast becoming a complex, transnational phenomenon that mixes the legitimate worlds of global telecommunications, banking and financial systems with a host of illegitimate enterprises that include illegal drugs, money laundering, human trafficking and white-collar economic crime.

Owing to the vast territory this phenomenon occupies, both in terms of its real dollar impact on law enforcement, lost revenue, environmental degradation and health expenditures, as well as its conceptual impact on our sociological understanding of crime, 
measurement of organized crime is inherently difficult to determine. In quantitative terms, it has only been since 2001 that the Government of Canada has undertaken to develop a measurement framework to assess the extent of organized crime in Canada and the feasibility of collecting national police-based data. In a 2002 feasibility study, the Canadian Centre for Justice Statistics (CCJS) readily acknowledges that data availability and quality issues are stymied by several factors, including the fact that criminal organizations tend to operate in secrecy, organized criminal offences (or "vice-type" offences) go largely unreported since few generate complainants or witnesses, and that there exists a 'disconnect' between detecting an offence and linking it to organized crime, given that front line officers may not be aware of the link. ${ }^{1}$ The CCJS study further revealed that major police services across the country were utilizing various definitions of organized crime and that, for research purposes, efforts would need to be focused on building consensus among Federal/Provincial/Territorial (FPT) partners toward a national definition of organized crime. That work is underway and a 2002 Delphi panel ${ }^{2}$ conducted under the auspices of the FPT Work Group on Organized Crime Research and Analysis brought together jurisdictional representatives to brainstorm and generate consensus on an operational definition suitable to all parties. With at least a common operational definition now in place, current, quantitative statistical data from FPT jurisdictions will become available within the 2005-06 fiscal year, although other

\footnotetext{
${ }^{1}$ Lucie Ogrodnik, "Organized Crime in Canada: An Investigation into the Feasibility of Collecting PoliceLevel Data" 2002. Catalogue no. 85-556-XIE. Canadian Centre for Justice Statistics. Ottawa: Statistics Canada.

2 "A Delphi panel features successive iterations of written feedback from a group of pre-selected experts. The panel for this project featured 29 individuals, drawn from organizations that would provide a range of policy, enforcement, and intelligence perspectives."

Beals, Lalonde \& Associates, "Report of the Delphi Panel on Operational Definitions for the Data Collection on Organized Crime" October 2002. [Unpublished]
} 
considerations essential to a fulsome understanding of organized crime continue to persist.

At the community level, several difficulties exist with regard to police-level investigations into organized crime. First and foremost, Canadian police agencies must operate within the rule of law, and as such are restricted - or conversely enabled - to the extent of the law as it exists at any point in time. Second, organized crime's "victimless" nature often precludes the production of a tangible witness or victim as would be the case in a more "mundane" criminal offence such as a physical assault or automobile theft. As a result, traditional "after-the-fact" reactionary measures will not suffice. This understanding was clearly noted by the Supreme Court of Canada in 1993 in $R . v$. Bond ${ }^{3}$ when the Court adeptly noted that the very nature of organized crime necessitates that police services adopt proactive investigations rather than wait to react to the "confessions of penitent drug traffickers" and the like. ${ }^{4}$ The flip-side to this understanding is that the police must then dedicate human and financial resources over extended lengths of time to the fight against organized crime and that undercover investigations are often years in the making, require tremendous inter-jurisdictional cooperation and must exercise a level of evolving and increasing ingenuity that is required to stay one step ahead of the criminal element.

As one particular focal point within this matrix of constantly evolving but closely related issues, the examination of police powers in the exercise of organized crime investigations offers an interesting and highly relevant lens through which to examine several of these issues at once. Amendments to the Criminal Code adopted in 2002 have

\footnotetext{
${ }^{3}$ R. v. Bond (1993) 135 A.R. 329.
}

${ }^{4}$ Ibid. 
provided for a limited criminal liability exemption for police officers in the conduct of organized crime investigations and will serve as the central issue for thematization and analysis in this research. This investigation will begin with a look at the 1999 Supreme Court of Canada ruling in $R . v$. Campbell ${ }^{5}$ that subsequently prompted a federal Department of Justice White Paper and public consultation on police criminal liability. This resulted in the January 2002 passage of Bill C-24 (Law Enforcement and Organized Crime), bringing into law a limited criminal liability exemption for police officers in the conduct of organized crime investigations.

As a matter of public policy alone, it will be worthwhile to examine this new strategy designed to infiltrate, destabilize and incapacitate organized crime operations. Analysis will be provided that examines both a range of concerns raised in the literature about entrapment and undercover police operations, as well as supporting arguments that favor the use of a limited criminal liability exemption as put forward by the federal government and those which can be inferred from an analysis of the Supreme Court of Canada ruling in Campbell. This paper will also situate these new enabling powers within the context of the National Agenda to Combat Organized Crime, as adopted by Federal-Provincial/Territorial (FPT) Ministers of Justice in September 2000. The research will be directed to providing a wider context to the introduction of the criminal liability exemption, while maintaining a focus on its relevance and effectiveness as a bold investigative tool necessary for law enforcement agencies to carry out the mandate public officials have tasked them with.

Specifically then, in recognition that organized crime represents an amalgam of diversely structured economic and socially corruptible forces and whose investigation 
presents distinct operational and legal difficulties to law enforcement, this research aims to analyze how the limited criminal liability exemption introduced in 2002 may serve to mitigate these difficulties while also serving to increase police effectiveness in their public mandate against organized crime. For instance, how can these newly adopted police powers be used effectively while also ensuring that they operate within both constitutional boundaries and a framework of accountability protective of police operations and the general public alike? This is the primary question the thesis will attempt to answer. An analysis of this question and a number of related issues is timely, particularly since it interweaves three critical areas in contemporary criminal justice, namely, organized crime, police powers and public policy. The intersection of these three areas provides a unique congruence of socio-legal issues that are worthy of examination each on their own, but should provide a more coherent and thorough analysis when examined together.

Within this analysis, consideration will also be given to the role and structure of accountability measures. If police officers are given permission to commit acts that would otherwise be in violation of the law, under what circumstances and through what channels of authority will that permission be granted? Further, how will these measures of accountability be demonstrated to the public and, most importantly, is the information that is presented to the public truly a reflection of progress in the fight against organized crime? Or, is the question of accountability really just a moot point within an environment already shrouded by operational secrecy and one in which progress is too often characterized by qualitative estimates? This last question is particularly difficult

${ }^{5}$ R. v. Campbell (1999) 1 R.C.S. 577. 
considering, as mentioned previously, the measurement of organized crime and its impact on Canadian society is still in its early stages.

Little doubt exists that the difficulty in measuring organized crime and the progress made in countering its occurrence is a central and recurring theme for both academics and government departments alike. In keeping with the National Agenda to Combat Organized Crime, research and evaluative work is being conducted to build a better common understanding of organized crime, but how this work develops over the short to long term will have a significant impact on the development of a reporting regime that reflects balanced, informative and verifiable information. In much the same way, police-authored annual reports on the use of the limited criminal liability exemption present distinct difficulties for fully assessing the work of Canadian police agencies and their collective impact on reducing organized crime. In particular, the research will examine the inherent pressures that impact on the presentation of the scope and diversity of organized crime activities in Canada, including how public perception of organized crime is influenced by media reporting and the zero-sum balance often played out between the leveraging of public security imperatives with civil liberties.

This balancing act of public security, often now intertwined with national security in light of the global 'war on terrorism', with individual civil liberties and privacy rights is an expected and arguably pronounced byproduct of the type of legislation brought forth by Campbell. However, does the limited criminal liability exemption point the way to similar, increasingly intrusive regulatory and legislative mechanisms that will test the limits of constitutionality? In the final chapter, this paper will discuss what is hypothesized as increasingly strong public support for tough public policy and criminal 
justice legislation, but which must be tempered with strategic focus, sound accountability frameworks and parallel research and development.

At the outset, let us be clear that this research bases its understanding of organized crime on the operational definition adopted by FPT partners in 2002, pursuant to a facilitated prioritization session, or Delphi panel. Specifically, an organized crime offence is understood as "any offence under Canada's Criminal Code or under other acts of Parliament committed for the benefit of, or in association with, a criminal organization." A criminal organization is understood as,

A static or fluid group of individuals who communicate, cooperate and conspire within an ongoing collective network and has as one of its main purposes or activities the facilitation or commission of offences undertaken or planned to generate material benefits or financial gain. ${ }^{7}$

The utility of using the FPT operational definitions for the purposes of this research is that is that they are broad enough to encompass the activities, motivation and characteristics of those who participate in organized crime activities, while going beyond the narrower, legalistic definition used in the Criminal Code. This broader definition reinforces several of the critical characteristics of organized crime and therefore its benefit lies in inculcating readers with a working definition that applies to a multitude of criminal organizations that may appear vastly different on the surface, but are bonded together by several underlying similarities; these include the factors such as criminal organizations fluctuate in size and scope, differ in their communicative relationships and endure over time.

In summary, this research will provide a thorough analysis of a relatively new instrument of public policy, explaining the socio-legal environment in which the limited

\footnotetext{
${ }^{6}$ Beals, Lalonde \& Associates.
} 
criminal liability exemption was conceived and assessing its merit as an investigative technique in the context of organized crime investigations. In the next chapter, the paper will begin with an examination of the 1999 Supreme Court of Canada ruling in Campbell, a landmark ruling that provided the federal Liberal Government with the most significant, though not exclusive, impetus for the development of Bill C-24. The chapter will also examine Bill C-24 itself, now enacted as sections 25.1-25.4 of the Criminal Code, in order to identify precisely how these new enabling police powers have been designed and are to be executed. In the third chapter, the paper will examine more closely the problem of organized crime in Canada as a means of giving greater context to the introduction of Bill C-24. Specifically, the paper will draw on a number of sources to examine the scope and impact of organized crime in Canada, as well as the inherent methodological difficulties associated with quantifying organized crime.

In the fourth chapter, the paper explores a range of perspectives and concepts, contrasting the federal government's apparent expediency with the widespread caution in the literature about expanding police powers, while at the same time focusing on a number of key constructs such as reasonableness and risk in a review of the consequences of undercover policing.

In the fifth and final chapter, the paper will demonstrate that despite the existence of valid concerns surrounding several unintended and unintentional consequences of undercover investigations, which without any doubt need to be addressed through a more rigorous accountability regime, the use of the limited criminal liability exemption can and will be a sparingly used, effective instrument of public policy. Further, the exemption provisions will serve to clarify in law, without ambiguity, the parameters within which

${ }^{7}$ Ibid, p. 10 
law enforcement agencies must operate when investigating organized crime. The paper also argues that the limited criminal liability exemption is a relevant and effective investigative tool, however the accountability framework that supports it far from measures up to what one should expect from a policy tool of this sensitivity and reach. Ultimately, this paper calls for the development of a national framework for undercover policing, one which would include guidelines acceptable to all jurisdictions in an effort to strengthen the limited criminal liability's accountability regime and further improve the transparency in which police services report on their progress to civilian authorities. 


\section{Toward a Limited Criminal Liability Exemption}

A pivotal decision in Canadian criminal law and procedure, $R$. v. Campbell examined a range of intimately connected issues that thread together a portrait of modern organized crime investigation. As is the case with all Supreme Court of Canada decisions, rulings emanating from the country's top court necessarily have national legal and often national policy - implications that go beyond the simple guilt or innocence of the accused involved. While the facts of the case were clear and unambiguous, the associated issues of solicitor-client privilege, abuse of process, the rule of law and the merits of extending a public interest immunity to law enforcement presented a distinct challenge for the Court to consider, all within the rubric of the "war on drugs" - a key component of the fight against organized crime.

As a bell-weather of police investigative procedure, $R . v$. Campbell had an immediate and unquestionable impact on the conduct of organized crime investigations in Canada. The Court's ruling ground to a halt many existing investigations, modified some and suspended others. ${ }^{8}$ Given that the Court had ruled that the investigative tactic utilized by the Royal Canadian Mounted Police (RCMP) in this case - a reverse sting operation was illegal due its contravention of the Narcotic Control Act, a legal vacuum resulted. This vacuum called into question long-established investigative techniques employed by law enforcement agencies across the country and thereby forced the shutdown of similar

\footnotetext{
${ }^{8}$ Justice Canada, "Law Enforcement and Criminality: White Paper" (June 2000) online: Justice Canada http://www.canada.justice.gc.ca/en/cons/lect.html (last modified: 24 April 2003).

See also, Jim Bronskill, "Court handcuffs police: RCMP" Ottawa Citizen 12 March 2001. A1-A2. See also, Royal Canadian Mounted Police, "Report on Plans and Priorities: 2001-2002" online: Royal Canadian Mounted Police http://www.rcmp-grc.gc.ca/dpr/rpp2001 e.htm . Both the 2001-02 and 2002-03 editions of the RCMP Report on Plans and Priorities (RPP) specifically mention the R. v. Campbell ruling as a key factor influencing the RCMP's operations, noting in 2001-02 that the decision has "prevented the police from using certain pro-active investigative techniques."
} 
narcotic and smuggling investigations. It was this lacuna in the law that most centrally provided the impetus for legislative recourse. While one must account for other environmental factors at play leading up to and during the period from 1999 to 2002 , the year Bill C-24 received Royal Assent, it was $R$. v. Campbell more than any other factor that precipitated the designation of a limited criminal liability exemption for police. In the next chapter, examination will be given to these other environmental factors, namely the heightened awareness and incidence of organized crime activities in Canada, which also helped to influence, justify and precipitate Bill C-24. In this chapter, however, the paper will examine in some detail the specific facts and analysis presented in R. v. Campbell.

\section{The Facts of $R$. v. Campbell}

In 1991, in an attempt to deliver a decisive blow to an illegal narcotic ring operating in the Windsor-London-Mississauga-Toronto corridor of southwestern Ontario, the RCMP initiated a reverse-sting operation using undercover police officers. The underlying motivation of the operation was to target the "executives" of the narcotic ring, rather than the small-time, expendable street-level pushers whose arrest and imprisonment often does little to deter larger-scale organized crime operations. What the undercover RCMP officers intended to do in this operation was to position themselves as sellers of a large quantity of cannabis resin, rather than as purchasers in a traditional sting operation - hence the "reverse" operation. However, prior to authorizing the operation, the RCMP - through Corporal Richard Reynolds - sought out the legal advice of the 
federal Department of Justice (DoJ), through the person of Mr. James (Jim) Leising, section head for DoJ's criminal prosecutions in Toronto.

After consulting with Mr. Leising and receiving what was believed to be a legal "green light" for the proposed operation, approval for the reverse-sting was provided by senior RCMP officers. The RCMP, with the aide of an informant, then found a potential purchaser in the appellant Shirose. Mr. Campbell later became involved in the deal as a financier. In January 1992, Campbell and Shirose agreed to pay $\$ 270,000$ (Cdn) for fifty kilograms of cannabis resin, whose street value was nearly $\$ 1$ million. When the sting came to a close, the appellants were charged with conspiracy to traffic in cannabis resin and conspiracy to possess cannabis resin for the purpose of trafficking. When the case went to trial, counsel for the appellants first sought to subpoena Mr. Leising from DoJ in order to learn the particulars of his conversation with Cpl. Reynolds on the topic of the reverse sting. When the subpoena was quashed on the grounds of solicitor-client privilege, defense counsel then sought a stay of proceedings in order to examine $\quad \mathrm{Cpl}$. Reynolds on his conversation with Mr. Leising. The request for a stay was also quashed on the same grounds. Subsequently, the appellant Shirose was found guilty and sentenced to six years in penitentiary. The appellant Campbell was also found guilty and sentenced to nine years in penitentiary and ordered to forfeit the purchase price paid to the police.

It is worthwhile to note that in her analysis at trial, Ontario Court (General Division) Justice Caswell considered the issue of entrapment by the RCMP. In her analysis, Caswell J. referred to a two-pronged test for entrapment; in that test, either the authorities must (a) provide an opportunity to persons to commit an offence without 
acting reasonably or acting mala fides, or (b) having a reasonable suspicion or acting in the course of a bon a fides investigation, they go beyond providing a mere opportunity and actually induce the commission of an offence. ${ }^{9}$ The trial judge found that the RCMP had acted with reasonable suspicion regarding both appellants and had not induced the offence, therefore there was no basis for finding that entrapment had occurred. The Ontario Court of Appeal subsequently agreed with the trial judge and concluded that there was no entrapment had occurred. However, Carthy J.A. did find fault with the RCMP in that while the Narcotic Control Regulations provided the police with protection where they come into possession of a narcotic as the result of a sting operation, there is no corresponding regulation that provided the police with immunity to sell a narcotic. Therefore, the actions of the RCMP were prima facia illegal. While Carthy J.A. pointed out that the RCMP's mandate requires them to seek out criminality in a number of ways, their mandate does not extend to methods that would otherwise be illegal for any other person. However, having stated this, the appellate judge concluded the RCMP's actions were not such that they would cause the public's conscience to be shocked if the convictions were allowed to stand. He therefore concluded that it was sufficient for him to point out the error of the RCMP's actions without being so "sanctimonious [as] to say that the rule of law ha[d] been eroded by these convictions and sentences." ${ }^{10}$ The appeal was therefore dismissed and the stage was set for the final appeal to the Supreme Court of Canada.

\footnotetext{
${ }^{9}$ R. v. Campbell [1999] 1 R.C.S. 577

${ }^{10}$ Ibid, 580.
} 


\section{The Supreme Court of Canada}

In his preliminary analysis of the facts at hand, Mr. Justice Binnie, who wrote for the Court, noted the immediate paradox of the case, namely that the RCMP was in contravention of the very law it was attempting to uphold, the Narcotic Control Act. In this way, he presented the task of the Court as that of an arbiter to find a balance between the necessary, yet difficult task of the police to enforce the law of the land with behavior that is injurious or shocking to the community's sense of decency. ${ }^{11}$ The Court was quick, however, to pronounce that the guilt (or innocence) of the appellants was by now a far-gone conclusion and that the only remaining matter was for the Court to consider whether the proceedings against them should be stayed based upon abuse of process by the police.

In its consideration of this question, the Court first noted that the rule of law must be applied equally to all, no matter what class of citizen or holder of office is in question. Although it was argued by the appellants that the illegal actions of the RCMP should alone disqualify any conviction against them, the Court first tipped the balance in favor of the police by stating that police officers "gain nothing personally from conduct committed in good faith efforts to suppress crime."12 The Court then applied the test for abuse of process, as set out in $R$. v. Jewitt [1985] 2 S.C.R. 128, in which trial judges are required to exercise judgment as to whether proceedings against an accused would violate a community's sense of fair play and decency. In correlating the test for entrapment as simply an application of the abuse of process, the Court found itself in agreement with the lower courts that no grounds for entrapment could be made. The Court reiterated the

\footnotetext{
${ }^{11}$ Ibid, 581 .
} 
Ontario Court, General Division, remarks that the police did not cross an inappropriate boundary by inducing the commission of an offence and further, that the appellants were willing participants in the transaction.

The Court then noted that the appellants could only now fall back on the assertion that the RCMP's actions were so shocking that they did in fact violate the community's sense of fair play and decency. In drawing this argument out further, the Court examined the issue of police illegality in more detail. While it noted that the issue of police illegality is itself of fundamental importance to the administration of the law, the Court also, and most significantly, pointed out that everyday police operations are by their very nature bound to - superficially at least - come into conflict with the law. Referring to the Alberta Court of Appeal in R. v. Bond, the Court emphasized that this situational police illegality is bound to occur,

Police involve themselves in high speed chases, traveling beyond posted speed limits. Police pose as prostitutes and communicate for that purpose in order to gather evidence. Police buy, possess, and transport illegal drugs on a daily basis during undercover operations. In a perfect world this would not be necessary but, patently illegal drug commerce is neither successfully investigated, nor resisted, by uniformed police peering through hotel room transoms and keyholes or waiting patiently at police headquarters to receive the confessions of penitent drug traffickers. $^{13}$

Bearing this in mind, the Court stated that judicial examinations of police illegality as the basis for a stay of proceedings are necessarily investigated on a case-by-case basis, lending favor once again to the inherent difficulty posed to the police by complex investigations. At the same time, however, the Court pointed out the "inescapable"14 conclusion that in this instance the RCMP's actions were illegal and that no extension of

\footnotetext{
${ }^{12} \mathrm{Ibid}, 584$.

${ }^{13}$ R. v. Bond (1993) 135 A.R. 329.
} 
Crown immunity could be afforded to the police force. The Mounties, like other police services, are independent of the executive arm of government and cannot be considered "agents" of the Crown when executing criminal investigations for the simple reason that to do otherwise would seriously cloud the line that separates police oversight with political direction. Rather, the Court went on to state that police officers hold a public office established in common law and subsequently reinforced by a number of statutes, for example the Royal Canadian Mounted Police Act, which require them to act in accordance with the law.

What came next in the Court's reasoning is central to its entire ruling and essentially formed the basis for the limited criminal liability exemption component of Bill C-24 that was to soon follow. The Court stated that, in recognition of law enforcement's duty to act in accordance with the law, "II]f some form of public interest immunity is to be extended to the police to assist in the 'war on drugs', it should be left to Parliament to delineate the nature and scope of the immunity and the circumstances in which it is

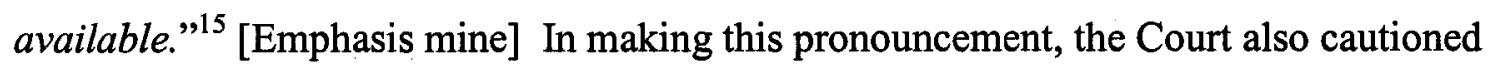
that such an exemption would need to be specific in nature and could not simply be used to justify police expediency. Otherwise, to legislate a general law enforcement exemption would force the courts to "constantly second-guess legislatures and assess the merits of social policies underlying criminal prohibitions", ${ }^{16}$ a role in which the Court wanted no part. In reaching this bold suggestion, it is clear that the Court felt comfortable and welljustified because of its reference to related legislative change and its own invocation of

\footnotetext{
${ }^{14}$ R. v. Campbell [1999] 1 R.C.S. 587.

${ }^{15}$ Ibid, 594.

${ }^{16}$ Perka v. The Queen [1984] 2 S.C.R. 232.
} 
public attitude. Specifically, the Court reasoned that since Parliament had already introduced the Controlled Drugs and Substances Act, an update on the now defunct Narcotic Control Act, which now permits the sale of narcotics by police in reverse sting operations, then these types of operations in and of themselves would not "shock the conscience of the community in such a way as to constitute an abuse of process." Therefore, in following this line of reasoning, it would not be that far off the mark, according to the Court's thinking, for Parliament to extend a similar level of limited criminal immunity to the police for other investigative measures.

It is at this juncture in the Court's ruling that marks the cut-off point for the essential interest of this paper. What follows in the Campbell ruling is a detailed analysis by the Court of solicitor-client privilege and, specifically, the merits of the Crown's argument that the RCMP's reliance on the legal go-ahead it received from DoJ was executed in "good faith", thereby preserving its secrecy and bolstering its defense against abuse of process charges by the appellants. The Court determined that, contrary to the ruling of the Ontario Court of Appeal, the appellants were entitled to the disclosure of the RCMP-DoJ communication and that their appeal should therefore be allowed in part, so as to allow for a new trial in which a stay of proceedings is considered based upon the specific interchange of communication between Cpl. Reynolds and Mr. Leising.

\footnotetext{
${ }^{17}$ R. v. Campbell [1999] 1 R.C.S. 598.
} 


\section{Law Enforcement and Criminality White Paper}

On the heels of the Campbell ruling, DoJ launched a Law Enforcement and Criminality White Paper in June 2000. The White Paper was a public consultation held by DoJ's Criminal Law Policy Section with the aim of soliciting the views of law enforcement, academics, non-governmental organizations and the general public on its proposed limited criminal liability exemption for police. The proposed legislation, in the form of several amendments to the Criminal Code, would directly respond to the Campbell ruling by extending to the police an additional enforcement tool that the Government deemed to be "in the public[s'] interest" and would allow police to "effectively carry out their duties." ${ }^{18}$ In support of its proposed legislation, DoJ noted in its White Paper that similar, though seemingly more restricted, provisions already existing in law that allow the police to commit acts that would otherwise be illegal, including activities related to the possession of proceeds of crime, possession of prohibited or restricted weapons and activities related to money laundering. ${ }^{19}$ The thrust of the White Paper was therefore in some respect similar in nature to the reasoning of the Supreme Court, by implying that the limited criminal liability exemption was not that great a step to go in law enforcement powers beyond that which already existed in law. And in less than a year from the launch of the White Paper in June 2000, the federal government introduced for First Reading its newest organized crime legislation in the form of Bill C-24 on April 15, 2001. By December $18^{\text {th }}$ of that same year Bill C-24 had received Royal Assent and subsequently came into force on January 7, 2002, save for the

\footnotetext{
${ }^{18}$ Justice Canada, "Law Enforcement and Criminality: White Paper" (June 2000) online: Justice Canada http://www.canada.justice.gc.ca/en/cons/lect.html (last modified: 24 April 2003), 4.
} 
law enforcement justification provisions which were proclaimed into force only on February 1, 2002 to allow time for the training of law enforcement personnel.

\section{Bill C-24 (Organized Crime and Law Enforcement)}

The organized crime and law enforcement measures contained within Bill C-24

constituted the eighth major domestic legislative or regulatory update since $1997 .{ }^{20}$ Since that time, a variety of measures were introduced by the federal government as it set its sights on curbing organized crime, including the earlier introduction of amendments to the Criminal Code that ushered in the concepts of "criminal organization" and "criminal organization offence", amendments to the Corrections and Conditional Release Act that removed accelerated parole eligibility for those convicted of organized crime-related offences, a new Extradition Act in 1999, and the creation of the Financial Transactions and Reports Analysis Centre of Canada (FINTRAC) in 2000.

The newest piece of legislation, Bill C-24, was multifold; it contained five key amendments to the Criminal Code. In addition to establishing a limited criminal liability exemption for law enforcement officials, its also introduced three new criminal offences dealing with participation in a criminal organization, introduced measures to protect members of the criminal justice system against intimidation, simplified the existing definition of "criminal organization" in the Criminal Code, and broadened the powers of law enforcement to seize the proceeds of crime, particularly those generated through organized crime activities. Therefore, although at the heart of Bill C-24 lay the limited

\footnotetext{
${ }^{19}$ Ibid, 7.

${ }^{20}$ Samuel D. Porteous, "Organized Crime Impact Study: Highlights" (1998) [On-line] Available: http://ww2.psepc-sppcc.gc.ca/Publications/Policing/1998orgcrim_e.asp (last modified: 10 April 2002).
} 
criminal liability exemption, the legislation also attempted to respond to a number of other recent pressures and influences related to organized crime activities. For instance, the act of intimidating members of the justice system proved to be an issue that hit close to home as it had been only earlier in 2000 when Bloc Quebecois Member of Parliament (M.P.) Yvan Loubier received death threats from local outlaw biker gangs and for a time required twenty-four hour police protection. ${ }^{21}$ The legislation also brought the Criminal Code definition of "criminal organization" into line with the United Nations definition of organized crime by reducing the number of participants required to constitute an organized crime structure from five to three. ${ }^{22}$ Speaking on the Bill, then-Solicitor General Lawrence MacAulay stated, "This bill will give police the tools they have asked for to bolster their ability to infiltrate, destabilize and dismantle criminal organizations.",23 Clearly, the Government thought that it had introduced a strong piece of legislation and took numerous opportunities in the House of Commons and through the media to relay its message that it was clamping down on organized crime. But would these new measures really be able to do the job?

Before that question can be answered, it is important that a closer examination be given to the specific sections of Bill C-24, particularly those that relate to the limited criminal liability exemption. In so doing, a basis will be provided upon which to give

\footnotetext{
${ }^{21}$ Dennis Bueckert, "Duceppe accepts RCMP protection" Ottawa Citizen 24 October 2000. See also, Ruth Walker, "Canada's biker war tests free assembly" Christian Science Monitor 26 September 2000.

${ }^{22}$ According to the United Nations Convention Against Transnational Organized Crime, "an 'organized criminal group' shall mean a structured group of three or more persons existing for a period of time and acting in concert with the aim of committing one or more serious crimes or offences established pursuant to this Convention, in order to obtain, directly or indirectly, a financial or other material benefit."

United Nations Convention against Transnational Organized Crime, GA Res. 55/25, UN GAOR, $55^{\text {th }}$ Sess., UN Doc. A/RES/55/25 (2001) 4.

${ }^{23}$ Justice Canada, "Government of Canada Steps Up Fight Against Organized Crime" (2001) online: Justice Canada http://www.canada.justice.gc.ca/en/news/nr/2001/doc_26096.html (last modified: 5 April 2001).
} 
more measured analysis in subsequent chapters of the arguments in favor of and against the law enforcement immunity provision. First, and most importantly, it is worth examining the principle upon which this piece of legislation is based and which itself is embedded in the Bill. According to Bill C-24,

It is in the public interest to ensure that police officers may effectively carry out their law enforcement duties in accordance with the rule of law and, to that end, to expressly recognize in law a justification for public officers and other persons acting at their direction to commit acts or omissions that would otherwise constitute offences. ${ }^{24}$

In laying out this principle, the Government is making a strong statement by linking the contravention of the law in certain circumstances with the public good. At the heart of the Government's argument is a conviction that organized crime syndicates are effectively investigated and dismantled only when law enforcement agencies are allowed to play ball on the same level. However, as will be examined below, the law enforcement immunity provision is by no means a blanket measure designed to give free reign to the police. Rather, controlled and supervised illegal police actions are, so goes the Government's argument, a matter of choosing one necessary evil over another. Borrowing from remarks made by former Chief Justice Antonio Lamer in Rothman v. $R$, DoJ reiterated in its White Paper that the investigation of crime, particularly of "shrewd and often sophisticated" criminals, "is not a game to be governed by the Marquess of Queensbury rules."25 One can infer from these types of remarks that the Government clearly felt under pressure to respond to the problem of organized crime - and the host of challenges its investigation presents to law enforcement - with bold and substantive

\footnotetext{
${ }^{24}$ Bill C-24, An Act to amend the Criminal Code (organized crime and law enforcement) $1^{\text {st }}$ Sess., $37^{\text {th }}$ Parl., 2001, cl. 2 (assented to 18 December 2001).
} 
policy measures, even when those measures would so likely raise concerns among traditional opponents of greater law enforcement powers.

One may assume that in order to allay some of these concerns, the Government included in its design of Bill C-24 a provision of direct civilian oversight. Specifically, in the case of members of the RCMP, it is the federal Solicitor General (now Minister of Public Safety and Emergency Preparedness), and for provincial and municipal police officers it is the provincial Minister responsible for policing, who alone can act as the "competent authority" to designate those public officers with the power to commit illegal acts or omissions. Further, the competent authority may only grant designations where a public authority composed of persons who are not peace officers is in place to review the public officer's conduct (e.g. Commission for Public Complaints Against the RCMP). In providing the authority to make designations, the bill attempted to provide some reinforcement of the thin line between civilian oversight and political direction by adding the proviso that the Minister acting as competent authority

... shall make designations ... on the advice of a senior official and shall consider the nature of the duties performed by the public officer in relation to law enforcement generally, rather than in relation to any particular investigation or enforcement activity. ${ }^{26}$

The bill attempted reinforce the notion that Ministers of the Crown cannot give political direction to specific law enforcement investigations, but can rather only give consideration to the more general scope and depth of those activities, based upon the policy advice they receive from senior officials. However, the bill does also allow room

\footnotetext{
${ }^{25}$ Justice Canada, "Law Enforcement and Criminality: White Paper" (June 2000) online: Justice Canada http://www.canada.justice.gc.ca/en/cons/lect.html (last modified: 24 April 2003), 2-3. See also, Rothman v. R., (1981) 59 C.C.C. (2d) 30 at 74.

${ }^{26}$ Bill C-24, An Act to amend the Criminal Code (organized crime and law enforcement) $1^{\text {st }}$ Sess., $37^{\text {th }}$ Parl., 2001, cl. 2(4) (assented to 18 December 2001).
} 
for senior law enforcement officials to themselves make designations under the law enforcement immunity provision in what it deems "exigent circumstances"27 when it is not feasible for the Minister to make such a designation and whereby the actions of the police officer would be justified by the circumstances of the case at hand. While one can speculate that this latter provision was built into the Bill to account for certain undeniable operational necessities in organized crime investigations, primarily where time is often of the essence, it is also a provision that requires particularly close attention and tracking for obvious reasons. It could be argued that the integrity of the immunity provision could easily be called into question if it is demonstrated that senior law enforcement officials have become too eager to make their own immunity designations, thereby by-passing the Minister and weakening the character of the designation as a tool to be used in select and carefully controlled circumstances.

In making a designation with respect to the law enforcement immunity provision, the competent authority may place conditions on the designation that limit its duration, the nature of the conduct involved and the acts or omissions that would otherwise be illegal. Within these parameters, three specific justifications must be met in order to substantiate a designation, namely that an officer

(a) is engaged in the investigation of an offence under, or the enforcement of, an Act of Parliament or in the investigation of criminal activity;

(b) is designated by the competent authority (or senior law enforcement official in an emergency designation); and

(c) believes on reasonable grounds that the commission of the act or omission, as compared to the nature of the offence or criminal activity being investigated, is reasonable and proportional in the circumstances, having regard to such matters as the nature of the act or omission, the nature of the investigation and

${ }^{27} \mathrm{Ibid}, \mathrm{cl}$. 2(6). Note that this type of designation is limited to a 48 hour period. 
the reasonable availability of other means for carrying out the public officer's law enforcement duties. ${ }^{28}$

Within this last subsection lies what may prove to be the most difficult and onerous aspect of the limited criminal liability exemption. Specifically, what exactly do "reasonable and proportional" grounds mean? And how will judgments exercised by front-line police officers and their superiors hold up to scrutiny against language that appears legally debatable in the clearest of cases, and more particularly in the instance of a complex criminal investigation? In a related subsection, police officers are given the latitude to bypass the authorization process altogether if extenuating circumstances exist such that the officer believes on reasonable grounds that an illegal act or omission is considered necessary to (a) save the life or safety of any person, (b) prevent the compromise of an undercover officer or confidential informant, or (c) prevent the imminent loss or destruction of evidence of an indictable offence. ${ }^{29}$ While these three conditions appear straight-forward, one or more of the conditions may well become the basis for a legal challenge if it can be demonstrated that an officer had the opportunity to choose a less injurious course of action, one that did not require the commission of an illegal act or omission, but still chose to exercise his discretion in favor of illegal selfauthorization. While several potential legal scenarios could be examined in respect of these provisions that attempt to accommodate extenuating circumstances, suffice it to say for the present that notion of "reasonableness" in this particular context may not be fully, or at least partially, examined until the limited criminal liability exemption is challenged in court and a binding legal opinion - or further instruction - is offered on the matter.

\footnotetext{
${ }^{28} \mathrm{Ibid}, \mathrm{cl} .2(8)$.

${ }^{29} \mathrm{Ibid}$, cl. 2(9b).
} 
It is also important to recognize that the limited criminal liability exemption may be extended beyond police officers to persons acting under their direction, in other words, to police informants participating in organized crime operations. Potentially more difficult to manage than that which relates to police officers, this provision is inherently fraught with difficulty in that it lends second-party immunity to civilians who must rely upon a belief that the police officer directing their otherwise illegal actions has the authority to provide that instruction. ${ }^{30}$ While this proviso may potentially save harmless a civilian owing to an honest belief in the authority of the police officer who directs the illegal act/omission, potential problems are not difficult to conjure up when one considers the shady character, background and general (un)trustworthiness of those most likely to be put in this position. This last point is, however, speculative and is raised only as a potential issue worth watching for in the future as case law around the limited criminal liability exemption develops.

Perhaps to reinforce the "limited" nature of the criminal liability exemption, certain limitations were written into framework, namely to mitigate any excessive or overindulgent use of the protection against specific acts that cannot be justified. For example, in no way can the negligent causing of death or grievous bodily harm, the willful attempt to obstruct or pervert justice, or conduct that would violate the sexual integrity or an individual ever be used under the protection afforded by the legislation. The limitation also goes on to explicitly state that the rules governing the collection of evidence are in no way compromised by any of the provisions contained in the legislation and that, therefore, the Charter protections governing evidence are not compromised.

${ }^{30} \mathrm{Ibid}, \mathrm{cl} .2(10)$. 
In relation to reporting on the use of the criminal liability exemption, Bill C-24 called for police officers to file descriptive written reports to their senior officers after the commission of the illegal act or omission, and also for cumulative annual written reports to be published by every competent authority. Specifically, the report must account for the number of emergency or exigent designations made, the number of written authorizations made under regular circumstances, the number of times acts or omissions were made by police officers without prior authorization and the nature of the conduct being investigated, as well as the nature of the acts or omissions conducted. However, in order to protect the integrity of ongoing criminal investigations and the identity of the police officers involved, the annual written reports are limited to relaying simple statistical data on the frequency by which the limited criminal liability exemption is applied and the generic context of its usage.

In recognition of these limitations, one may challenge this reporting and accountability regime as a system in which 'true' and 'fulsome' accounts of how and when the limited criminal liability exemption has been applied may never been known, and further, that they may indeed by held back by law enforcement agencies for reasons of self- protection and preservation. While a thorough discussion on the merits and difficulties associated with the limited criminal liability exemption, and undercover policing in general, will take place in the fourth chapter, suffice it to say for the present that legislatures are caught in a tough dilemma. The public policy debate surrounding the issue of organized crime is steeped in politics, with multiple actors, including political parties, police services, government departments, academics and non-governmental organizations all vying for attention and, in many cases, public resources. Elected 
politicians must attempt to strike a balance between that which they know to be true and accurate, as presented to them by senior public servants and police officials, and to a lesser extent academics/NGOs, with the intense pressure from their constituencies to "get tough" on (organized) crime and to do so by whatever means necessary. Lock the door and throw away the key goes the saying.

As an example, "Safe Homes and Safe Communities" has been a federal government policy priority for more than a decade in Canada and, like all political tag lines, is one that can never be completely fulfilled. No matter what amount of money the government invests, nor what legislative tools the Government passes, crime will continue to exist. Therefore, the public policy question becomes one of balance, integrity and measured successes. Whether the limited criminal liability exemption will prove to be a balanced public policy option that achieves measurable successes in a manner minimally injurious to the public's sense of evenhandedness and to our notion of the rule of law remains an unanswered question - and a minimally researched one. However, for the present, we must rely on existing research to understand as best we can the complex nature of organized crime in Canada and to situate the limited criminal liability exemption within that context. Only then can we begin to understand the policy drivers and inherent pressures that led to its creation. In the next chapter, the paper will present an overview of the organized crime situation in Canada - its size, its scope, its implications - and position this data as the groundwork for a later analysis of whether the limited criminal liability exemption was truly justified and whether it has yet to prove its worth. 


\section{Finding a Source}

As this paper had first laid out in its introductory remarks, the central difficulty associated with tracking organized crime is that it is a highly expansive and nebulous topic that, as researchers have come to understand, is more correctly identified for its fluidity and adaptability than for stagnate and long-standing stereotypes. These "truths" about organized crime in Canada, as elsewhere, have made the task of collecting methodologically sound, empirically-based research a significant challenge for governments and academics alike. As will also be discussed in greater detail in this chapter, any examination of organized crime need also account for the fact that public discussions on organized crime are pervaded by "big P" politics and, certainly, "small P" politics. Political agendas matter, as do the public policy preferences of those who elect our politicians, whether or not they are in tune with evidence-based policy choices. For the purposes of this chapter then, whose central purpose is to sketch out a succinct and accurate overview of organized crime in Canada, the challenge becomes one source and citation.

This paper has chosen to avoid relying on a host of qualitative and quantitative sources. Instead, it will depend to a large measure on one source. The central question core to this research after all is not whether organized crime exists, but whether a particular public policy instrument can make any difference in reducing the size and scope of that reality. As for the challenge of defining that reality, no one view, nor plurality of views, will fully encapsulate the diversity of opinions on or measurements of organized crime. That stated, data collected on an annual basis by the Criminal Intelligence Service of Canada (CISC) provides the reader with a flavor for the scope, 
impact and trend analysis integral to the examination of organized crime in Canada. CISC clearly brings a police-centric view to the problem of organized crime, but if after all what we are after are the broad strokes, one should take this data with a grain of salt, if one needs to.

\section{The Criminal Intelligence Service of Canada (CISC)}

CISC, operational since 1970 and comprising over 380 law enforcement partners, serves as Canada's national police intelligence-gathering bureau, producing the only integrated, forward-looking annual report on organized crime in Canada. Since its first annual report on the state of organized crime in Canada in 1997, CISC has adopted an approach consistent with the National Coordinating Committee on Organized Crime $(\mathrm{NCCOC})^{31}$ by categorizing types of organized crime by their traditionally-associated perpetrators. In other words, the problem of organized crime has been parceled into the categories of Asian-based organized crime (AOC), Eastern European-based Organized Crime (EEOC), Outlaw Motorcycle Gangs (OMG), Organized Crime at Marine Ports, Airports and Land Border Areas, and Traditional (Italian-based) Organized Crime (TOC), along with several other categories capturing emerging issues of concern (sexual exploitation of children on the Internet, Aboriginal-based organized crime, organized crime and the diamond industry, street gangs, technology and crime, and the illicit movement of firearms).

\footnotetext{
${ }^{31}$ The National Coordinating Committee on Organized Crime (NCCOC) is composed of federal, provincial and territorial officials who determine national policy priorities and assess emerging concerns in the area of organized crime.
} 
While this approach has afforded researchers a neatly organized format for following developments in organized crime, the packaging may have proved to be too neat. By organizing data in this manner, CISC and its contributing partners, such as the R.C.M.P., have maintained rigid representations of Canada's organized crime problem in which emphasis has consistently been placed on perpetrators rather than the impact of organized criminal activity or examining the defining characteristics of these categorizations. This approach provides some difficulty for the simple reason that while we may know, to some extent, who is committing organized crime, we know very little of its collective impact on our economy, social ties, or criminal justice system. In an attempt to address this critique, CISC has modified its annual report for 2005 and chosen to more strategically present its data in two categories: (1) the characteristics and methods of organized crime; and (2) an examination of several key criminal markets dominated by organized crime. Examination will be provided within this chapter of both methodologies (pre- and post-2005) in an effort to piece together a clear overview of the organized crime problem in Canada.

It should be pointed out at this point that primary reliance on the CISC reports within this paper is a necessary starting point given that other than these reports, scarce data, quantitative or qualitative, has been collected on the phenomena of organized crime in Canada. Simply put, from the literature review conducted through the course of this research it is clear that little, if any, empirical data exists on the problem of organized crime in Canada. Moreover, what qualitative and anecdotal information does exist often reflects organizational self-interest, is clearly aligned to a political ideology or generally lacks analytical rigor. As noted by Margaret E. Beare, "while most issues related to 
social control or moral regulation have a political aspect to them, discussions related to organized crime and transnational crime are steeped in politics."32. Therefore, information on organized crime that does exist must often be pieced together to form a general impression of the greater problem given the reluctance of law enforcement agencies, for example, to provide information that is highly detailed. In fact, police services produce minimal information on organized crime other than occasional press releases or "fact sheets" when a large bust has just occurred or a major criminal conviction has been achieved. For the practical and justifiable reasons of the police not wanting to compromise the integrity of ongoing investigations or put into jeopardy the safety of officers involved in those operations, performance measurement for public reporting purposes is generally weak in the police sector. While this certainly does not absolve police services from accounting for resources received and progress achieved, the difficulties of data collection with respect to organized crime are an important discussion point and will be touched on again at a later point in this chapter.

For the reasons just outlined, one ought to, on a general basis, import a healthy dose of scrutiny into any organized crime publication. That said, merit still exists in examining the findings of CISC's annual reports given that in research terms they are a relatively long-standing source of qualitative data on organized crime in Canada. It is also worth noting that these reports are by no means exhaustive on the topic of organized crime, yet they provide a high-level overview of current pressing issues and areas of emerging concern. A highly in-depth examination of any one type of organized crime

\footnotetext{
${ }^{32}$ Margaret E. Beare, "Facts from Fiction - Tactics and Strategies of Addressing Organized Crime and Organized Criminals" (Canadian Police College Seminar Series: Perspectives on Organized Crime in Canada, Canadian Police College, 21 June 2000) (2000) online: Nathanson Centre for the Study of
} 
activity is not within the scope of this paper and the analysis that follows is meant only to give readers an informed sketch as to the scope and depth of the organized crime problem in Canada.

\section{Current Trends in Organized Crime in Canada}

Referring back to the categories of organized crime outlined previously, the 2004 edition of the CISC annual report notes that Asian-based organized crime (AOC) continues to operate primarily in British Columbia's Lower Mainland region and in the greater Toronto area, but still exerts significant influence across the country due to its significant involvement in the illicit drug trade. Eastern European-based organized crime (EEOC), concentrated in Ontario, exerts a more diversified criminal portfolio by engaging in strategic partnerships with other organized crime groups in Canada and internationally. While EEOC's primary criminal endeavor is payment (credit/debit) card fraud, it is also involved in the export of stolen luxury vehicles, drug importation and trafficking, extortion, prostitution, money laundering and the smuggling of humans and contraband. Similarly, Outlaw Motorcycle Gangs (OMGs) are also known for their diversified involvement in a range of illegal activities, but like AOC, they concentrate their efforts primarily in drug trafficking ${ }^{33}$. The Hells Angels - the most publicly notable OMG in Canada according to research conducted for the Department of Public Safety and

Organized Crime and Corruption http://www.yorku.ca/nathanson/Publications/facts.htm (last modified: 21 June 2000).

${ }^{33} \mathrm{CISC}$ notes that trafficking in cocaine, marijuana and methamphetamine constitute the core of the Hells Angels drug enterprise. 
Emergency Preparedness Canada ${ }^{34}$ - continued to exert a stranglehold on criminal activity across the country, despite law enforcement efforts in recent years to curb their presence. CISC notes that the Hells Angels now operate thirty-four chapters in Canada with approximately 500 members and, given that its association with street gangs across the country provides it with a continuous recruiting pool of potential new members, the argument can be made that that number is likely to rise or at least remain consistent in future years, barring any heavy and concentrated law enforcement crackdowns on their operations.

On the other end of the spectrum of criminal sophistication, one of the Hells Angels' more adept and prolific partners is that of Traditional (Italian-based) organized crime (TOC). The Hells Angels and TOC are noted to have a symbiotic relationship, working in mutually beneficial associations where illegal gaming, drug trafficking and the facilitation of money laundering is concerned. Concentrated within Montreal, Hamilton, Niagra region and the greater Toronto area, and to a lesser extent Calgary and Vancouver, TOC has shed its "traditional" hierarchical structure and streamlined its operations by morphing into multi-ethnic cellular structures more capable of adapting to the fluidity of the criminal market. Its presence in port and border cities has facilitated cooperation with the Hells Angels and other independent crime groups to profit from the vulnerability of marine ports, airports and land-border crossings to the flow of illegal commodities. Due to their vast physical size, receipt of continuous flows of legitimate goods in which illegal goods can be interspersed and the availability of a workforce susceptible to corruption

\footnotetext{
${ }^{34}$ Pheonix Strategic Perspectives Inc., "Canadian's Views on Organized Crime: Final Report on the Findings of a Qualitative Study, July 2005”, p. 16, [unpublished: archived at Public Safety and Emergency Preparedness Canada].
} 
and infiltration, points of entry into Canada form the last major organized crime priority under the banner of the NCCOC, aside from specific organized crime groups. It is understandable why the Government has invested heavily in border management and security in recent years, creating, for example, the Canada Border Services Agency (CBSA) in December 2003 as part of the new Portfolio of Public Safety and Emergency Preparedness, in addition to the creation of fourteen Integrated Border Enforcement Teams (IBETs) that combine police, customs and immigration officials from Canada and the United States in joint effort teams that target cross-border smuggling.

Less prevalent, but potentially just as harmful, other forms of organized crime in Canada, as well as particular criminal markets, have merited continual attention by CISC. These include Aboriginal-based organized crime (ABOC), the illicit movement of firearms, trafficking in human beings, sexual exploitation of children, street gangs, technological crime and infiltration of the diamond industry. While much more attention could be provided to each of these issues on its own, the key point to the discussion in this chapter is that organized crime takes on a broad range of forms and exerts its perceptible and imperceptible impact on communities large and small, urban and rural and across socio-economic boundaries. But how do we know this? What do we know about for certain about the impact of this seemingly amorphous phenomenon and how may we define its key characteristics, if any?

In its 2005 annual report, CISC shifts gears by providing an analysis of organized crime that departs from its previous methodology by providing detailed characteristics of organized crime as a phenomenon, rather than by type of perpetrator. In this way, organized criminal operations are characterized as being "networked and opportunistic" 
with fluid-like structures and associations that may be cell-based and multicultural. ${ }^{35}$ Another key characteristic is that criminal associations are forged based on mutual need and may endure through long periods of time or may dissolve quickly. Hence we know that these associations are not static, but rather fluid-like and dependent upon trust, timing and opportunity. We also know that violence and intimidation form key defining characteristics and serve as primary methods for conducting criminal activity, facilitating the commission of offences, instilling fear in communities and intimidating participants in the criminal justice system. It is this violence associated with organized criminal activity that is most acutely understood by Canadians, forming the central overriding image of what the lay-person corresponds to organized crime. ${ }^{36}$ It is this linkage between recurring trends, as reported by CISC, and attitudinal perceptions, as recently researched by the Department of Public Safety and Emergency Preparedness ${ }^{37}$, that reinforces a collective understanding that violence is inherent and pervasive to organized crime, in addition to its fluidity and opportunistic nature.

One need also know that in addition to the more brutal side of organized crime, the technological savvy of organized criminal associations allows them to engage in a host of criminal activities such fraud, identity theft, and extortion through modern day technology. Though far less noticeable on the public's radar, the incidence of technology-based crime is indicative of the adaptability of organized crime to its surroundings and its adeptness at taking advantage of criminal opportunities not yet legally regulated or with minimal oversight and enforcement. Examples of Internet-based

\footnotetext{
${ }^{35}$ Criminal Intelligence Service Canada, "2005 Annual Report: Organized Crime in Canada" (2005) online: Criminal Intelligence Service Canada. http://www.cisc.gc.ca/annual report2005.htm (last modified: 16 August 2005).
} 
fraud, for example, include occurrences of "pharming" and "phishing" whereby domain name systems (DNS) are infiltrated by hackers ("pharming") resulting in web-users being illegally re-directed to targeted websites where legitimate personal information, such as banking and credit card data, is "phished" out of unsuspecting victims by seemingly legitimate financial institutions. PhoneBusters, the Canadian anti-fraud call centre, reports that for 2003 , the last year in which statistics are available, more than 13,000 Canadians fell victim to identity theft, losing a net value of over $\$ 21,500,000{ }^{38}$ It is this technological know-how that has in recent years driven the Government of Canada's lawful access initiative in an attempt to update regulatory and legislative provisions that would enable law enforcement with the legal means to pursue organized crime on the Internet and to compel Internet service providers to disclose the records of its users ${ }^{39}$. While this initiative is also now targeted towards anti-terrorism efforts, it is a part of the broader array of public policy initiatives aimed at trying to keep one step ahead, or at least abreast, of organized crime.

\section{The Media and Organized Crime - Shaping Our Perceptions}

In examining just what is the problem of organized crime in Canada, this paper has avoided the abundant use of statistics and speculative dollar figures that attempt to quantify the scope of the problem. The primary reason for this has been alluded to already, namely that national, methodologically-sound empirical data on organized crime

\footnotetext{
${ }^{36}$ Pheonix Strategic Perspectives Inc., p. i.

37 Ibid.

${ }^{38}$ PhoneBusters, "Identity Theft Complaints" (2003) online: PhoneBusters. http://www.phonebusters.com/english/statistics_EO3.html

${ }^{39} \mathrm{See}$ http://www.psepc-sppcc.gc.ca/policing/organized crime/factsheets/high tech crime e.asp See also: http://canada.justice.gc.ca/en/cons/la_al/
} 
in Canada simply does not exist - and what does exist, like the heavily relied upon 1998 Porteous Study undertaken for the former Department of the Solicitor General of Canada, is simply a best-guess estimation ${ }^{40}$ - and secondly, until such data is developed and becomes widely available, "guesstimations" will only serve to confuse a topic already skewered towards the sensational in the eyes of the general public.

Understanding what the public understands of any public policy issue is also a critical factor that researchers and public policy makers must bear in mind. Without a clear sense of what the public's attitude towards any issue is, governments cannot craft public policy tools that resonate with the public and fall within the general scope of acceptable preventative, corrective or enforcement action. While smart public policy choices should not always and in every case necessarily be popularity contests, it is important that governments find balance in policy choices that attempt to address the root causes of a problem, but yet do so in a manner that educates the public where education is warranted, fall within the rule of law, and achieve measurable results and that can provide some insight toward future choices. Taking these considerations into mind, this would be an appropriate time to ask the question, "what does the Canadian public know about organized crime?" The simple answer is "quite a lot", as well as "not very much at all". To understand why this seemingly contradictory response occurs, it is necessary that we examine several studies conducted in recent years that attempted to answer this same question and all of which generally come to the same conclusions.

\footnotetext{
${ }^{40}$ Samuel D. Porteous, “Organized Crime Impact Study: Highlights” (1998) [On-line] Available: http://ww2.psepc-sppcc.gc.ca/Publications/Policing/1998orgcrim e.asp (last modified: 10 April 2002).
} 
In 2002, Judith Dubois examined the relationship between media coverage of organized crime and its impact on public opinion for the R.C.M.P., revealing three critical points. ${ }^{41}$ First, Dubois found that criminal events as reported in the media are not necessarily those that are the most significant in terms of broader trends, frequency, or representative of the offenders involved. More often it is the case that the media reports on atypical or extreme crime, choose stories that involve vulnerable victims or invulnerable offenders, or simply provide reports that are pessimistic about the criminal justice system.

Dubois' second finding is that a relationship exists between the commission of violent crimes against the public and its subsequent perception of risk and its fear of crime. While research concerning the fear of crime by Julian Roberts reveals that levels of fear of crime have remained fairly stable in recent years and may be attributable to the falling crime rates, this is not necessarily at odds with Dubois' assertion that temporary periods of shock and knee-jerk reaction follow episodes of violent crime as reported by the media. ${ }^{42}$ With a plethora of television news magazines and tabloid shows from which viewers can gather information, what is presented as "news" is often showcased with minimal complexity or context and leads to simplistic crime-fighting preferences. This is buttressed by the conclusions of Beare and Ronderos who, in 2001, examined over 1,200 Canadian news print articles aiming to extrapolate consistencies in the reporting of organized crime. What they found was that of the sample examined, rhetoric in the form

\footnotetext{
${ }^{41}$ Judith Dubois, "Media Coverage of Organized Crime: Impact on Public Opinion?" Royal Canadian Mounted Police: June 2002. Online: Royal Canadian Mounted Police. http://www.rcmp-grc.gc.ca 42 Julian Roberts, "Fear of Crime and Attitudes to Criminal Justice in Canada: A Review of Recent Trends 2001-2002" Solicitor General Canada: November 2001. Online: Public Safety and Emergency Preparedness Canada. http://www.psepc-sppcc.gc.ca/publications/corrections/FearOfCrime_e.asp\#Executive (last modified: 20 September 2002).
} 
of vague threats posed by organized crime or themes or moral panic pervaded nearly a quarter of all the articles, while only $14 \%$ offered any critical questioning or insight. ${ }^{43}$ Further, only $40 \%$ of the articles offered any evidence to support the story reported on, the bulk of that evidence coming from the police. ${ }^{44}$ These findings suggest that the media's influential role in the shaping of public attitudes has reinforced sensationalized imagery as the face of organized crime, which has in turn reduced the conveyance of less titillating, but no less important criminal occurrences. This fits directly with Dubois' third major finding.

Dubois' final conclusion is by its very nature a by-product of her second assertion, which is that if the media favors one type of coverage, it does so at the expense of all other types. She cites, for example, coverage of environmental crime in Hillsborough County, Florida, where out of a total of 878 instances of chemical spills tracked over a ten year period, only nine were reported to the Tampa Tribune. The public's perceived lack of interest in these types of white-collar crimes is generally seen as the culprit for the minimal attention paid to such instances, yet it is this pandering to public opinion by media outlets that continues to help reinforce stereotypical views.

\section{Public Opinion and Organized Crime - What Do We Really Know?}

Closer to home, research on the public's attitude toward organized crime conducted for the Department of Public Safety and Emergency Preparedness (PSEPC) in 2005 reveals a blend of the stereotypical and an elementary grasp of the issue. The

\footnotetext{
${ }^{43}$ Margaret E. Beare and Juan Ronderos, "Exploratory Review of Media Coverage on Organized Crime in Canada: 1995-2000". Justice Canada: March 2001. Online: Nathanson Centre for the Study of Organized Crime and Corruption. http://www.yorku.ca/nathanson/Publications/nathanso.htm
} 
research, conducted with sixteen cross-country focus groups, revealed that Canadians' general overriding impression of organized crime is one of violence and violent activities. ${ }^{45}$ Participants also demonstrated a high degree of consistency in the identification of actors and activities associated with organized crime. Most respondents pointed to biker and ethnic gangs as the main perpetrators of organized crime and believed these groups to be involved primarily in lucrative activities such as the drug trade, prostitution, pornography and money laundering. While participants generally agreed that organized crime is a serious and growing issue, a disconnect existed in that most participants could not connect the impact of organized crime to their daily lives. In fact, the findings demonstrate that Canadians are generally unable to distinguish between organized crime and other "run of the mill" types of crime, often conflating youth or street gangs, for example, within the rubric of organized crime. This confusion then led to a general inability to assess the performance of the federal government's efforts in fighting organized crime, other than generally believing that the government's present efforts are either too lax or lenient. These findings are consistent with prior public opinion research conducted for the Department of Justice (DoJ) in 2001, wherein only $24 \%$ of Canadians said they were satisfied with the federal government's efforts to fight organized crime, though levels of awareness of federal efforts were also generally low. ${ }^{46}$ The research conducted for PSEPC also aligned with the DoJ research in several other areas.

\footnotetext{
${ }^{44}$ Beare and Ronderos, p. 41

${ }^{45}$ Pheonix Strategic Perspectives Inc., p. 6

${ }^{46}$ Ipsos-Reid, "Public Views on Organized Crime". Justice Canada: February 2001. p. 15
} 
Compared with other national priorities, organized crime - or simply crime for that matter - consistently ranks behind other high-profile priorities, particularly healthcare and education. However, when Canadians are asked to identify the most important crime priorities, organized crime ranks highest compared to other issues such as gang violence, youth crime, or drug trafficking. ${ }^{47}$ Not surprisingly, Canadians also tend to be in general agreement when it comes to the types of governmental responses necessary to combat organized crime. Tougher sentences, increased police powers and stricter immigration policies rank highest among Canadians' public policy preferences. According to an Ipsos-Reid poll conducted for the Department of Justice in 2001, Canadians are strongly in favor $(78 \%)$ of providing police and prosecutors with additional powers to fight organized crime, even if these additional powers might infringe on individual rights, and $75 \%$ are in agreement with police officers having the capability to infiltrate gangs through the commission of illegal offences. ${ }^{48}$ While figures like these should not come as a surprise given the high level of confidence in which the public holds the police compared to other institutions (e.g., governments, academia and media) (IpsosReid, 2001; Pheonix Strategic Consulting Inc., 2005), serious caution is warranted.

\section{Measuring Success?}

We already know that police services, on an individual basis, produce minimal publicly available qualitative or quantitative data on organized crime. Therefore, how can we know whether the law enforcement activities in which they engage, whether new measures recently provided by legislatures or more traditional investigative techniques,

\footnotetext{
${ }^{47}$ Ibid, p. 8
} 
are really making a difference? Secondly, even if more data were available, what sort of national performance measurement framework would need to be implemented to organize that data and which could then produce the tactical and strategic analyses necessary to address questions of performance, evaluation and resource allocation?

In what is probably the first Canadian study of its kind examining the lack of performance measurement and evaluation for organized crime control strategies, Thomas Gabor of the University of Ottawa examines eighteen such strategies, along with the overarching impediments to their effective assessment. According to Gabor, despite the vast terrain that the study of organized crime could conceivably occupy, the use of highly rigorous, methodologically-sound research designs are "virtually non-existent" 49 in assessing the impact of organized crime control strategies. To date, no law enforcement initiative has been tracked either from the outset, or after the fact, to determine whether it achieved a statistically significant reduction in certain illegal activities. Gabor cites three key contributing factors for this lack of academic literature, namely a lack of consensus on the definition of organized crime, issues related to data collection including heavily biased, sensationalistic or self-serving information, and the use of crude and varied performance measures.

Having already touched on the difficulties associated with the definition of organized crime in the first chapter, it only needs to be emphasized at this point that within academia and government, a duality of definition has long persisted. In other words, disagreement as to whether organized crime is better characterized by its

\footnotetext{
${ }^{48} \mathrm{Ibid}, \mathrm{p} .4$
} 
enterprise nature, that is to say its opportunistic profit motives, or by certain activities that require a degree of organization (e.g., money laundering and protection rackets) has until recently, at least, impeded a satisfactory approach to data collection. ${ }^{50}$ With regard to data collection issues, Gabor highlights much of what has been complained of by other authors, including the lack of consistent data collection by government agencies, an overreliance on police arrest rates as a measure of criminal activity and government documents that tend to paint organized crime as conspiratorial and alien to society rather than a byproduct of its weaknesses.

The third tenet of Gabor's argument is that what performance measures have been utilized thus far are so varied and generally crude that, when examined together, we only see a hodgepodge of measurements. Body-count measures, for example, attempt to quantify arrest and conviction rates, but on their own they do not import any information related to the impact of the actual crimes committed, nor do they tell us whether the law enforcement strategies that led to the arrests were successful in and of themselves, or if it was really a matter of additional police resources paying off. Similarly, the use of inference is inherent to those measures that attempt to quantify the scope of an illicit market. Given that there are many unknowns in estimating the size of an illegal market, speculative figures should be regarded with a fair dose of caution, particularly since they tend to take on a life of their own once released. Gabor also notes that even if we were to

\footnotetext{
${ }^{49}$ Thomas Gabor, "Assessing the Effectiveness of Organized Crime Control Strategies: A Review of the Literature". Justice Canada (Research and Statistics Division): March 31, 2003. Online: Justice Canada http://www.justice.gc.ca/en/ps/rs/rep/2005/rr05-5/index.html (last modified: 23 June 2005).

${ }^{50}$ As mentioned earlier though, preliminary progress on this issue has been achieved by the consensus reached among federal and provincial/territorial officials to an agreed-upon operational (i.e. research-based) definition of organized crime. Significant work remains, however, in the implementation of the definition through the Uniform Crime Reporting Survey 2 (UCR2), operated by Statistics Canada. Estimates are that
} 
see a reduction in the size of one illegal market, we should be cautious given that organized crime may have simply re-directed resources from one market to another as a compensatory measure. Likewise, the quantification of organized crime (e.g., scope and volume) is near impossible if, by definition, organized crime is a fluid activity in which resources are continuously laundered and interspersed with legitimate businesses.

Efforts to measure the harm produced by organized crime are also fraught with difficulty if we consider several key factors. First, organized crime, unlike other more traditional crimes, is often victimless; those persons on the wrong end of a drug deal gone bad, for instance, are unlikely to file a police complaint or to view themselves as "victims" in the traditional sense. Secondly, the sheer number of variables involved in the computation of harm, whether physical, economic, community-based or societal, are so numerous, the complexity of the challenge is daunting. For that very reason, educated estimations based on specified sets of individually estimable variables may be the best option possible, but what that might entail and how it could be developed for each prism (e.g., physical, societal, etc.) is certainly beyond the scope of this paper. That said, what do we know of the organized crime control strategies that have been employed by police and prosecutors and how might this information guide our analysis of the limited criminal liability exemption?

Drawing on a literature review of existing academic and governmental publications on organized crime, Gabor's evaluation strategy is to first assign an evidence rating (nil, limited, significant) to each category of crime control strategy and to then assign an overall effectiveness rating (low, low-moderate, moderate, moderate-high, 
high). Based on this methodology, Gabor concludes that of the eighteen strategies examined, four fall within an overall effectiveness rating of "low", one as "lowmoderate", four as "moderate", three as "moderate-high", zero as "high", and six escape a rating altogether due to "insufficient data". 51 While this approach is highly subjective, it does accomplish three ends. First, it reinforces Gabor's initial assertions that because of definitional issues, data-related issues and crude and varied performance indicators, we are left with little else than subjective assessments to measure the effectiveness of organized crime control strategies. Second, it makes clear that when considered as a whole, the results achieved by the strategies now employed to counter organized crime are at best mixed. A full third of the strategies investigated lacked sufficient data to even guess as to their effectiveness. Based on those findings, one cannot conclude that those strategies are therefore ineffective, but nor can one trumpet their effectiveness either. Third and more germane to this paper, Gabor's evaluation highlights several of the key concerns related to undercover police operations and the use of informants as discussed in the literature. The salient points raised include the observations that undercover work is inherently dangerous and pervaded by the use of manipulation, participants (whether police officer or informant) are susceptible to corruption, temptation and duplicity, and that undercover officers tend to be less experienced investigators and may lack sufficient

2006 fiscal year.

51 "Low": Prosecuting organized crime kingpins; measures to combat money laundering; seizure and forfeiture of assets; and reducing the supply of illegal goods and services.

"Low-Moderate": Undercover operations and informants.

"Moderate": Prosecutions through the use of taxation laws; Strike and drug task forces (US); Electronic surveillance; prosecuting persons involved in organized crime.

"Moderate-high": Witness protection programs; Injunctions, divestitures, trusteeships; Increasing regulation and establishing public benefit corporations.

"Insufficient data": Anonymous juries; Witness immunity; Investigative grand juries; Citizens' and police commissions and community-based efforts; Intelligence analysis; legalization of certain goods and services. 
field supervision. While Gabor concluded that the use of undercover operations and informants only warranted an overall effectiveness rating of "low-moderate", more extensive examination of the issue is necessary in the following chapter. Specifically, a closer analysis is needed if we are to carefully weigh the cautions noted by Gabor in his research with three countervailing and essential factors: (1) the impact of R. v. Campbell, (2) the prior analysis of what we know to be verifiable and accurate about the scope and impact of organized crime in Canada, and (3) a public policy environment focused on results and, counterproductively, under significant pressure to "get tough on crime". The proceeding chapter intends to position these three factors as critical environmental considerations that must be accounted for when considering the contribution of the limited criminal liability exemption to the fight against organized crime, as well being significant policy drivers that support the continued existence of these provisions in the Criminal Code. 


\section{$\underline{\text { An Environmental Scan }}$}

An honest assessment of any public policy initiative is not possible without at least conducting a cursory examination of the critical environmental factors that contributed, directly or indirectly, to its introduction. This paper has attempted through previous chapters to lay bare those factors that formed the boundaries around the centerpiece of Bill C-24, which introduced the limited criminal liability exemption into law. The paper has noted that the Supreme Court of Canada, in its majority decision in Campbell, exercised a significant amount of deference to the R.C.M.P. by pointing out that situational police illegality is bound to occur within the course of everyday law enforcement investigations, and that this illegality must be assessed on a case-by-case basis, and not collated into one judicial strike against law enforcement practices writ large. The Supreme Court went on to note that, at the time of its judgment, several statutes already provided law enforcement with the occasion to conduct otherwise illegal activities in the course of an investigation, and therefore, the extension of a more generally applicable law enforcement justification would not be that far of a legal stretch. The Court clearly noted, however, that it would be up to Parliament to create that justification in law and to delineate the scope and nature of its use.

We also found through the course of the Department of Justice's subsequent consultation process on its proposed limited criminal liability exemption that the Supreme Court's ruling in Campbell significantly curtailed existing and planned organized crime investigations, creating an operational legal black hole for the R.C.M.P. and other law enforcement agencies. One may conceivably infer from this that the federal police force 
and its provincial and municipal counterparts were eager to work with the federal government to address this operational void.

For its part, the federal government would likely have been eager as well to demonstrate leadership on a pressing policy file that had in recent years been showered with media attention, not to mention received significant exposure and commitment in the realm of FPT relations. For example, FPT Ministers responsible for Justice had, in September 2000, adopted the National Agenda to Combat Organized Crime at their annual meeting in Iqaluit, Nunavut, committing jurisdictions to strengthening legislative and regulatory tools. Shortly thereafter, in October 2000, the House of Commons Standing Committee on Justice and Human Rights sub-committee on Organized Crime released its final report. The government was clearly in a position in which it needed to act. However, in order to assess the subsequent introduction of Bill C-24, some degree of inference on the part of the reader is required if we are to surmise what the government considered critical considerations integral to its legislative proposal. While Cabinet confidence precludes researchers from knowing exactly what discussions took place around the Cabinet table, a reasonable person may infer four key points from this series of events.

First, it seems acceptable to infer that the government would have considered that public support would be on its side. Polling conducted for the government around this time confirmed that the public perceived organized crime to be a serious problem and was willing to extend a significant amount of latitude to law enforcement agencies to deal with it, even at the expense of individual liberties ${ }^{52}$. Second, it seems reasonable to infer

\footnotetext{
${ }^{52}$ Ipsos-Reid, "Public Views on Organized Crime". Justice Canada: February 2001.
} 
that the government would have taken the opportunity provided by the Campbell ruling to introduce a comprehensive approach to police illegality in the course of criminal investigations, rather than attempt to retro-fit individual statutes and create a mish-mash of exemptions and authorities. Third, the government would likely have believed its approach to be inclusive in that the provisions contained within Bill C-24 covered all conceivable scenarios in which law enforcement would utilize such an exemption (i.e., pre-planned criminal investigations, situational (unplanned) illegality, and exigent circumstances). Fourth, one may infer that the government anticipated concerns regarding oversight of the new investigative powers and therefore included an accountability scheme within the actual legislative provisions rather than relying solely on existing oversight mechanisms. Taken together, these four inferences lead one to conclude that, from the government's perspective at least, it was acting in due course and exercising due diligence by creating a comprehensive yet limited criminal liability exemption that would be prudently administered and adhered to within the confines of ministerial authority.

\section{$\underline{\text { An Academic Perspective }}$}

A review of academic literature on the topic of police powers and criminal liability reveals less enthusiastic support for such a scheme as adopted by Parliament. Although relatively few articles exist that deal exclusively with this topic, those that door those that even touch on the edges of the topic - are generally pervaded by a sense of unease for expanding police powers, particularly in the absence of legislative approval. Cohen argues that although legislatures may deem it necessary to accede to more 
intrusive police powers, these powers should necessarily be tempered by considerations of privacy and balance. Referring to electronic surveillance investigations, Cohen argues that, where less intrusive means are available, the more minimally intrusive option ought to be employed by the police and that under no circumstances should law enforcement be granted the authority to use violent or destructive acts in the course of their investigation. ${ }^{53}$ Stober likewise argues that it is sometimes necessary for police to resort to special techniques to achieve their desired ends, however limits must be placed on the extent to which those tactics may be employed. ${ }^{54}$ More specifically, the type of activity to be avoided is a police "fishing expedition" which may presumably lead to the creation of entrapment, in which the police go beyond simply providing the accused with an opportunity to commit a crime and actually induce the commission of an offence.

Brauti and Welsh further recognize that police may have to commit illegal acts in the course of an investigation, however this behavior leaves them vulnerable to criminal prosecution and jeopardizes the prosecution of the accused. ${ }^{55}$ At the same time, Brauti and Welsh also acknowledge that the courts have been reluctant to impose a stay of proceedings based upon a determination that an abuse of process has occurred owing to questionable police conduct. The authors cite four prominent cases (Bond ${ }^{56}$, Matthiessen $^{57}$, Lore $^{58}$ and Campbell ${ }^{59}$ ) in which defense counsel raised the issue of abuse of process and in each of the cases the court rejected the motion. The authors note that

\footnotetext{
${ }^{53}$ Stanley Cohen, "The Investigation of Offences and Police Powers" (1981) 13:3 Ottawa Law Review, 549.

${ }_{54}^{54}$ Michael Stober, "The Limits of Police Provocation in Canada" (1992) 34 Criminal Law Quarterly. 290.

${ }^{55}$ Peter Brauti and Candice Welsh, "Illegal Police Conduct in the Course of a Bona Fide Investigation" (1999) 43 Criminal Law Quarterly, 64.

${ }^{56}$ R. v. Bond (1993), 3 S.C.R. 329

${ }^{57}$ R. v. Matthiessen (1995), 134 C.C.C. (3d) vi (S.C.C.)

${ }^{58}$ R. v. Lore (1997), 132 C.C.C. (3d) vi (S.C.C.)
} 
the Supreme Court has made it clear that illegal police conduct does not always translate into an automatic stay of proceedings and that a line in the sand exists between "structural illegality" - that which is planned and deliberately undertaken by the police - and "situational illegality" - that which occurs when the accused has encouraged or prompted the police to engage in illegal conduct.

Another way of analyzing this line in the sand is to borrow from the analysis provided by Gail Reaney in her examination of the issue, albeit in the American context. In the United States, a more generalized law enforcement justification exists in common law and which, according to Reaney, has been minimally clarified or expanded upon by American superior courts. ${ }^{60}$ In an attempt to develop a set of legal parameters around the law enforcement justification (by tying its validity to an analysis of the application of due process) Reaney argues that one must test the 'reasonableness' of the police officer's actions. However, one may then ask, "What constitutes reasonableness?" According to Reaney, the answer lies in the distinction between violent and non-violent actions. Actions which are malum prohibitum are "allowed in any number of circumstances without penal sanction" whereas actions which are malum in se are "only permitted in a very limited number of instances." ${ }^{, 61}$ A court's subsequent examination of an officer's actions therefore rests on whether the police officer's action was evil in and of itself (malum in se) or simply in violation of a positive law (malum prohibitum). Other considerations cited by Reaney in her examination of American case law include whether the officer's actions were in contravention of a professional code of ethics or code of

\footnotetext{
${ }^{59}$ R. v. Campbell (1999), 1 R.C.S. 577

${ }^{60}$ Gail M. Reaney, "Crossing the Constitutional Line: Due Process and the Law Enforcement Justification" (1999) 67 Notre Dame Law Review, 745.
} 
conduct, and whether the officer circumscribed his actions so as to do no more than is necessary and proper. ${ }^{62}$ This analysis provides an interesting congruence of issues pertinent to the Canadian context since the designation of the limited criminal liability exemption rests upon a three-pronged test, wherein the most challenging tenet of the test is a demonstration that the act or omission "... is reasonable and proportional in the circumstances. ..."Without any subsequent Canadian case law (further to Campbell) on which to draw further instruction, Reaney's examination of the test of 'reasonableness' may well provide valuable insight into how Canadian courts may approach this issue when, not if, it comes before them.

Another valuable perspective from which to draw is the analysis by Brodeur concerning the consequences of undercover policing operations. According to Brodeur, four categories of consequences exist, namely those which are (1) desirable (from a law enforcement perspective) and intended, (2) desirable and unintended, (3) undesirable and intended, and (4) undesirable and unintended. ${ }^{63}$ Under the first category, crime repression and crime prevention are cited as two central, positive outcomes of undercover policing. Brodeur cautions, however, that without reliable statistics to track the effectiveness of undercover policing operations, any assessment of the amount of crime repressed will be speculative at best. Similarly, crime prevention could also occur as a result of undercover operations in that subsequent criminal plots may be averted or foiled on account of a particular operation, although one could never know exactly the extent of what has not happened. As a related by-product of crime prevention, Brodeur's second

\footnotetext{
${ }^{61}$ Reaney, G., 784.

${ }^{62}$ Ibid, 789.
} 
category counts the deterrence of crime as a desirable, yet unintended outcome. He notes that deterrence is most likely to occur in cases where undercover policing operations have not been used before, hence the element of surprise captured by the police may well lend an element of luck to the operation and (temporarily) thwart criminal operations. Other outcomes that fall within this second category include the disorganization of organized crime groups and the maintenance of police morale. Each of these, however, should cautiously be considered temporary outcomes at best. If we recall from our earlier examination, two key characteristics of organized crime are fluidity and adaptability. This should hasten us to remember that organized crime groups can exert an elasticity that allows them to recover from even significant strikes by law enforcement. Police morale is therefore also reasonably tied to the ebb and flow of successful undercover operations and, conversely, the failure of an operation to produce the intended results (i.e., criminal convictions).

In the third category, Brodeur asks us to grapple with the unsightly side of undercover policing by examining those outcomes which are undesirable, but still intended. For example, the use of informants by law enforcement agencies is generally viewed more as a pre-condition of undercover policing operations than as a consequence. However, in its simplest form, does this relationship not boil down to the licensing of criminals? In other words, do undercover operations not implicitly provide a legal "green light" to criminals to continue committing criminal acts, albeit in the cause of something greater than their individual act? Further, what should one make of the relationship

\footnotetext{
${ }^{63}$ Jean-Paul Brodeur, "Undercover Policing in Canada: A Study of Its Consequences" in Cyrille Fijnaut and Gary T. Marx, eds. Undercover: Police Surveillance in Comparative Perspective, The Hague (The Netherlands): Kluwer Law International. 1995, x, 337 p. at pp. 71-102
} 
between handlers and informants if, during the course of an investigation, each side were to become deeply involved (e.g., emotionally, sexually) beyond that which is strictly prescribed by legal and operational necessity? There are obvious operational and legal implications in scenarios such as these, not to mention moral questions, and yet does the ultimate response to these questions - indeed to the continuance of undercover policing in general - not rest in a comprehensive assessment of risk? Before attempting to answer that question, let us first finish examining Brodeur's arguments and then return to the topic of risk.

Continuing with the third category of undesirable, but intended consequences of undercover policing, Brodeur also warns of potential outcomes such as the statutory violation of confidentiality, the facilitation of crime, and the subversion of the due process of the law. In the first instance, a possible consequence of undercover policing could be the violation of privileged relationships (e.g., doctor-patient or solicitor-client privilege). In such scenarios as these, undercover officers attempt to extract incriminating evidence against suspects by recruiting doctors or solicitors to act as informants and thereby to forfeit information about their clients in violation of their professional oaths. In the second instance, the term "crime facilitation" refers to all those subversive aspects of undercover policing that have as their end goal the commission of an offence, whether that be through means of instigation, entrapment, trickery or framing. While each of these methods imparts a degree of cunning on the part of the police, this paper argues that the use of trickery is an inherently beneficial aspect to undercover police work, so long as it remains within the scope of the law and does not assume an intent to act with malice, as would be the case for patently illegal practices like instigation, entrapment and framing. 
However, more on that point shortly. Other points of concern, still within Brodeur's third category, include the subversion of the due process of law and the targeting of noncriminal opponents. In each of these instances, third parties are unwittingly used to achieve a law enforcement end through information that is known to be false. For instance, the due process of law would be violated if an informer perjures himself before a judge in order to bolster the police's case for the authorization of a judicial warrant (e.g., for the purpose of electronic surveillance). In such a scenario, the police are aware that the informer has lied to the judge, but are willing to accept the illegal act if it plays to their benefit in the cause of a broader investigation. Concerning the final point in this category, the targeting of non-criminal opponents occurs when informers snitch on innocent third parties as a means of revenge and thereby initiate a series of legal headaches for the accused. This sort of intelligence gathering can conceivably run the gambit of revenge tactics from the smearing of someone's personal or professional reputation to a potentially dangerous and life-threatening situation, such as detention and deportation, if it occurs in the realm of national security.

The fourth category of consequences attributed to undercover policing according to Brodeur includes those that are both undesirable and unintended. These consequences are those that most clearly expose the underside of undercover policing and which must be most vigilantly guarded against. Outcomes that fall under this category include the incidence of police corruption due to environments characterized by high levels of secrecy and large sums of money, the loss of police identity due to a breakdown in the separation between informer and handler, and the creation of shields for misconduct. Under the latter outcome, the concern rests with undercover police officers that 
potentially become susceptible to the secrecy in which they work and find themselves more and more accustomized to "being in the wrong place at the wrong time". In other words, officers who become consistently exposed to opportunities to commit illegal acts may begin to fall victim to behavior unworthy of their post (e.g., drinking/being drunk on the job, becoming too close to informants, spending too much time in seedy establishments, etc.).

Another potential outcome on the "double negative" side of undercover policing is the creation of innocent casualties. For example, this could include scenarios in which an innocent person is mistaken for an informer and is murdered in retribution or where an undercover police officer is so far under deep cover that he is not even recognized by his colleagues and is mistakenly killed. Now, how could such a scenario as the latter occur? Brodeur answers this question by hypothesizing that cases of mistaken identity are a result of police disorganization in the realm of undercover policing. Owing to the secretive nature of the operations in general and the exchange of information on a "need to know basis" in particular, gaps in communication and information can result, leading not only to strained relationships between actors within the police system, but also to scenarios of mistaken identity such as those outlined above.

Perhaps the most damning indictment against undercover operations that Brodeur puts forward is one that speaks to undercover policing's greatest and potentially most pervasive risk, which is the de-legitimization of the criminal law. When undercover policing operations go terribly wrong and when they become publicly exposed, as in the case of the demise of the R.C.M.P.'s Security Service following the McDonald Commission in 1984, the entire criminal justice system takes a black eye. Further, one 
may reasonably posit that it takes but only one such incident by one agency to call into question the policing and law enforcement operations of an entire country. Therefore, is it really all worth the risk?

Brodeur's answer to that question appears to be that he is not at all certain. He concludes his paper by noting that the dichotomy between intended and unintended consequences of undercover policing is too rigid of a distinction, and that what really matters is that all these consequences "entail" as a result of undercover policing. These consequences, simply put, are the price to be paid for certain police practices. Whether or not they are intended is beside the point. It is at this juncture that Brodeur calls into question the so-called doctrine of necessary evil. Brodeur cautions us to ask, if we as a society are to support police activities that could result in consequences such as all of those explained thus far, are we trading one evil - that of (organized) crime - for another, seemingly lesser evil - sometimes morally questionable, sometimes potentially illegal police practices?

\section{Managing and Mitigating Risk - Guidelines for Undercover Work}

In order to answer that question, the paper will next examine whether the use of guidelines for undercover policing can potentially manage and mitigate the occurrence of undesirable and unintended consequences. Although this question cannot be fully answered, given that we can never fully know the incidence of that which does not occur, an examination of undercover policing guidelines does provide certain indicators. For example, undercover guidelines can tell us the scope of activities prescribed and prohibited by a particular police service. They can also provide a useful account of the 
internal processes that document, review and authorize undercover policing operations. Further, we can identify the priorities and focus that police organizations place on undercover policing, whether that is inclined toward administrative details or toward proscribing particular investigative techniques. Lastly, this type of analysis can provide some insight into whether the risks associated with undercover policing can reasonably be managed and curtailed by internal and external processes and oversight.

In a 1994 survey of police services in the 100 largest cities of the United States concerning the use of undercover policing guidelines, Hamilton and Smykia discovered an interesting dichotomy. What they found may not be surprising, but it may be instructive for the Canadian context. Of the 100 services studied, 87 services indicated that they employed undercover policing techniques, 64 of which indicated that they had guidelines for such operations while the other 23 indicated that they did not. ${ }^{64}$ Those respondents that had guidelines indicated that they had been instituted for a variety of (sometimes overlapping) reasons, including supervisory and administrative concerns (32), legal issues (18), safety concerns and the reduction of confusion and stress for the undercover officer (15). Twelve respondents indicated that their guidelines were developed as a response to problems encountered before guidelines were established, including adverse publicity, lost or dismissed prosecutions and lawsuits against the police department. Eleven respondents indicated that guidelines were developed to meet accreditation standards and five indicated the training of new undercover officers as the central reason for their development.

\footnotetext{
${ }^{64}$ Henry Hamilton and John Ortiz Smykia, "Guidelines for Police Undercover Work: New Questions About Accreditation and the Emphasis of Procedure over Authorization" Justice Quarterly, Vol. 11, No. 1, March 1994, 144-145.
} 
What is interesting about these findings, beyond the diversity of reasons for which police services develop guidelines in the first place, is the fact that more than half (34) of the services with guidelines emphasize procedure over authorization. In other words, most of the guidelines in place concern themselves primarily with administrative issues such as the recruitment of undercover officers, the chain of command, how equipment is issued, how reports are filed and how to account for the use of money utilized in undercover operations. This is in contrast to authorizational guidelines that concern themselves with when and how to conduct undercover operations. These types of guidelines provide detail on what types of investigations will be authorized, what controls will be established and how compliance with the guidelines will be ensured. While there is clearly importance to having administrative controls in place and having them effectively communicated amongst the ranks, one might reasonably suppose that in the realm of undercover operations, internal controls over substantive police work would be valued over the more superficial details of bookkeeping. However, what this study really provides for us - in the absence of a similar study in Canada - is a thumbnail sketch of that which could conceivably be covered under the auspices of undercover policing guidelines.

An interesting example of guidelines that integrate both procedure and authorization, but emphasize authorization, are those of the Federal Bureau of Investigation (FBI). Specifically, the U.S. Attorney General's Guidelines on FBI Undercover Operations provide detailed direction and clearly defined parameters around what is acceptable to the Department of Justice in undercover work, and what procedures must be adhered to in order to review and approve those activities. At the outset, the FBI 
guidelines identify five key risks that must be assessed by any official considering the development of a proposal to initiate undercover operations; the official must consider:

(1) the risk of personal injury to individuals, property damage, financial loss to persons or businesses, damage to reputation, or harm to other persons; (2) the risk of civil liability or other loss to the Government; (3) the risk of invasion of privacy or interference with privileged or confidential relationships; (4) the risk that individuals engaged in undercover operations may become involved in illegal conduct; and (5) the suitability of Government participation in the type of activity that is expected to occur during the operation. $^{65}$ Beyond the requirement for approval at the local level through the appropriate Special Agent in Charge (SAC), operations that include either "fiscal circumstances"

${ }^{65}$ United States Department of Justice, "Attorney General's Guidelines on FBI Undercover Operations: Revised 11/13/92" Online. (US Department of Justice) Available:

http://www.usdoj.gov/ag/readingroom/undercover.htm

${ }^{66}$ According to the FBI Guidelines, an undercover operation involves fiscal circumstances if there is a reasonable expectation that the undercover operation will:

(a) Require the purchase or lease of property, equipment, buildings, or facilities; the alteration of buildings or facilities; a contract for construction or alteration of buildings or facilities; or prepayment of more than one month's rent;

(b) Require the deposit of appropriated funds or proceeds generated by the undercover operation into banks or other financial institutions;

(c) Use the proceeds generated by the undercover operation to offset necessary and reasonable expenses of the operation;

(d) Require a reimbursement or compensation agreement with cooperating individuals or entities for services or losses incurred by them in aid of the operation; or

(e) Exceed the limitations on duration or commitment of resources established by the Director for operations initiated at the field office level.

${ }^{67}$ According to the FBI Guidelines, sensitive circumstances are involved if there is a reasonable expectation that the undercover operation will involve:

(a) An investigation of possible criminal conduct by any elected or appointed official, or political candidate, for a judicial-, legislative-, management- or executive-level position of trust in a Federal, state, or local government entity or political subdivision thereof;

(b) An investigation of any public official at the Federal, state or local level in any matter involving systemic corruption of any government function;

(c) An investigation of possible criminal conduct by any foreign official or government, religious organization, political organization, or the news media;

(d) Engaging in activity having a significant effect on or constituting a significant intrusion into the legitimate operation of a Federal, state or local government entity; 
FBI Headquarters through the office of the Director or designated Assistant Director, and in the case of sensitive circumstances, through the Undercover Review Committee (URC).

The URC, composed of members of the FBI and members of the Criminal Division of the Department of Justice, functions as a sounding board and consultation point for proposed undercover operations. Members of the URC are permitted to consult with a range of individuals within their respective organizations in order to further clarify positions and to reach consensus on the proposal. In Canada, the R.C.M.P. has not made public any similar set of undercover guidelines, however, in the absence of such public guidelines, the review process in the American context provides for a number of interesting points of discussion.

First, the American provisions provide a clear delineation between those undercover operations that may be deemed low-risk and those that may be deemed high-

(e) Establishing, acquiring, or using a proprietary;

(f) Providing goods or services which are essential to the commission of a crime, which goods and services are reasonably unavailable to a subject of the investigation except from the Government;

(g) Activity that is proscribed by Federal, state, or local law as a felony or that is otherwise a serious crime...

(h) A significant risk that a person participating in an undercover operation will be arrested or will supply falsely sworn testimony or false documentation in any legal or administrative proceeding;

(i) Attendance at a meeting or participation in communications between any individual and his lawyer;

(j) A significant risk that a third party will enter into a professional or confidential relationship with a person participating in an undercover operation who is acting as an attorney, physician, clergyman, or member of the news media;

(k) A request to an attorney, physician, member of the clergy, or other person for information that would ordinarily be privileged or to a member of the news media concerning an individual with whom the news person is known to have a professional or confidential relationship;

(1) Participation in the activities of a group under investigation as part of a Domestic Security Investigation or recruiting a person from within such a group as an informant;

(m) A significant risk of violence or physical injury to individuals or a significant risk of financial loss;

(n) Activities which could result in significant claims against the United States arising in tort, contract, or for compensation for the "taking" of property;

(o) Untrue representations by a person participating in the undercover operation concerning the activities or involvement of any third party person without that individual's knowledge or consent. 
risk. The FBI guidelines provide an introductory analysis of risk that must be calculated in each and every proposed operation, but then go on to further separate between low and high risk operations according to the existence of fiscal and sensitive circumstances, in which case the presence of either specifically defined circumstance necessitates further review by a bureaucratically-mixed review board. That review board, the URC, has the mandate and authority to accept or reject proposed operations and to broadly consult other government partners during its deliberation process. Further, its composition of individuals belonging to more than one government agency minimizes the risk that dissenting views will not be heard and that a single agency does not become overexcited with its own authority, resulting in a virtual rubber-stamp process. Secondly, the FBI guidelines, just as the provisions contained in C-24, provide for a limited number of justifications to engage in otherwise illegal activity in the absence of authorization. In both the American and Canadian contexts, authorization in extenuating circumstances is vested in officers themselves, such that they are legally entitled to commit an illegal act if it has as its purpose to maintain the integrity of evidence, prevent the compromise of the identity of an undercover agent or to prevent death or serious bodily injury. Prohibitions placed on that extenuating authorization are also strikingly similar in that both American and Canadian contexts prevent the negligent use of violence and the perversion or obstruction of justice, however, only the Canadian context - which as we should be reminded is specifically written into the Criminal Code - specifically prohibits the violation of the sexual integrity of an individual. A third and interesting point of comparison between the American and Canadian contexts is that the final approval for the commission of otherwise illegal acts or omissions in Canada normally rests with at the 
political level (e.g., Ministerial-level), with exceptions, rather than at the bureaucratic level, as in the United States (e.g., FBI Director).

While it is not immediately clear why this decision was made in the Canadian context, one may reasonably infer that it is linked to the doctrine of Ministerial responsibility. It is likely that the sensitivity of the proposed limited criminal liability exemption provision heightened the inclination during the consultation and drafting process to vest final authority at the ministerial level, given that Cabinet would presumably not want to delegate-down to the bureaucratic level too much of its "green light" from the Supreme Court. However, whether the authorization comes from the Minister, or in the case of certain exigent circumstances as described earlier in this paper, from senior police officials, there (publicly) exists no corresponding duty to consult a review body, as is the case in the United States.

This difference is perhaps the most striking distinction between the American and Canadian contexts, wherein the review and publication process for undercover operations is exercised in a very divergent way. An important caveat to this particular analysis, however, is to point out at the outset that the Canadian procedure described herein derives from that which has been implemented through the Criminal Code, whereas in the United States the process derives strictly from bureaucratically adopted guidelines rather than from statute since the American liability exemption exists only in common law, not statute. Irrespective of this difference in origin, it is still beneficial to examine the application of the two systems because each is particularly telling of the style in which the exemption is managed. According to the FBI guidelines, the URC is compelled to provide an annual report on each undercover operation to the Director of the FBI, the 
Attorney General, the Associate or Deputy Attorney General and the Assistant Attorney General (Criminal Division), whereas in Canada designations are assigned by either a senior police official or by the Minister him/herself, annual reports by police services are prepared for the appropriate (federal/provincial) Minister and - key to the distinction subsequently tabled in Parliament. It is also interesting to briefly note that the American guidelines are unclear as to whether undercover operations could potentially be reviewed by an external agency (i.e. beyond the URC), such as in Canada where a specific role exists for bodies such as the Commission for Public Complaints Against the R.C.M.P. to investigate at arms-length alleged police wrong-doing.

Based on these distinctions, it is difficult to say for certain whether either system is more transparent than the other or if public accountability is served better in one nation than the other. Consider first that, in the American system, government guidelines dictate that there must exist an internal review committee. This committee is charged with controlling, for the large part, the authorization process for the most complex and sensitive undercover policing operations. Yet in the Canadian system, it is unclear whether such a mechanism exists in practice as the mandating statute calls only for authorization to be served by a single competent authority (i.e., the Minister, with exceptions). In the American system, the FBI's URC appears to prepare more fulsome annual reports based on the learned experience of each and every undercover operation which is then presumably incorporated into planning and training processes to the benefit of future operations. These reports are, however, not made public. In Canada, annual reports are public documents and yet they provide scant detailed information other than an indication of how many authorizations were approved and only the briefest of details 
concerning the circumstances for which they were approved. To be fair, the R.C.M.P. may very likely have developed guidelines to manage undercover operations generally, or the exercise of the limited criminal liability exemption in particular, and yet in the absence of being wholly or partially made public, the public is left in a position in which it can only guess as to the fact that appropriate internal controls are in place. While it goes without saying then that public disclosure concerning undercover policing guidelines on the part of the R.C.M.P. and other major services would be a positive step forward and generate an enhanced level of transparency, let us move on to examine the Canadian reporting mechanism more thoroughly.

\section{What Are the Results So Far?}

In Canada, two annual reports on the law enforcement justification provisions have so far been tabled in Parliament by the Minister of Public Safety and Emergency Preparedness, pursuant to section 25.3 of the Criminal Code. These reports, for the years 2002 and 2003, indicate a limited use of the provisions thus far by the federal police force. In 2002, the Minister reported that the R.C.M.P. made two temporary designations under the limited criminal liability exemption (i.e., in the absence of Ministerial approval) due to exigent circumstances. The Minister also reported that eleven authorizations were made for directing another person to commit a justified act or omission that would otherwise constitute an offence, no authorizations were granted to officers to commit an act or omission that would otherwise constitute an offence and, finally, no officers proceeded with illegal acts or omissions without the senior official's written 
authorization. $^{68}$ In 2003, the Minister reported to Parliament that no temporary

designations were made, that six authorizations were granted for directing another person

to commit a justified act or omission that would otherwise constitute an offence, that no

authorizations were granted to public officers to commit justified acts or omissions and

that no public officers proceeded without a senior official's written authorization. ${ }^{69}$

Based on these figures, then, what interim conclusions are to be drawn from these results

as reported by the Minister and what future directions can be implied by the seemingly

circumspect use of the limited criminal liability exemption?

${ }^{68}$ Public Safety and Emergency Preparedness Canada, “Annual Report on the Law Enforcement
Justification Provisions Pursuant to Section 25.3 of the Criminal Code 2002" Online. (Public Safety and
Emergency Preparedness Canada). Available: http://www.psepc.gc.ca/publications/policing/
20030611 e.asp

According to the Annual Report, the two temporary designations related to an investigation into alleged offences of assault, aggravated assault, assault with a weapon, theft, causing a disturbance, obstruction and mischief. Justified acts or omissions that would otherwise constitute offences under the Radiocommunication Act and the Radio-communication Regulations were committed.

According to the Annual Report, five of the authorizations directing another person to commit an act or omission related to an RCMP investigation into the trafficking of stolen or fraudulent personal identification. Justified acts or omissions relating to the possession and/or purchase of identification documents were committed. In five other instances, the RCMP was investigating the smuggling and sale of contraband liquor. Justified acts or omissions relating to purchasing, possession or making a false customs declaration for contraband liquor and/or tobacco products were committed. In one instance, the RCMP was investigating a firearms offence. A justified act or omission relating to the possession of firearms was committed.

${ }^{69}$ Public Safety and Emergency Preparedness Canada, "Annual Report of the Law Enforcement Justification Provisions: 2003" Online. (Public Safety and Emergency Preparedness Canada). Available: http://www.psepc.gc.ca/publications/policing/lawenforce04 e.asp

According to the Annual Report, two of the authorizations directing another person to commit an act or omission related to an RCMP investigation into the alleged distribution, fabrication or acquisition of fraudulent passports. Justified acts or omissions related to the possession of a forged passport were committed. In two instances, the RCMP was investigating the alleged distribution, sale or smuggling of contraband tobacco. Justified acts or omissions related to the possession of improperly stamped tobacco were committed. In one instance, the RCMP was investigating the alleged sale or distribution of counterfeit art and counterfeit documents. Justified acts or omissions relating to the buying and receiving counterfeit documents were committed. In one instance, the RCMP was investigating a drug distribution network. Justified acts or omissions relating to the possession of stolen goods, theft over $\$ 5000$ and conspiracy to commit an indictable offence were committed. 
On first glance, these statistics appear to reveal a highly circumspect use of the limited criminal liability exemption provision, leading one to believe that the R.C.M.P. has exercised a fair degree of restraint during the early life of the broadened legal powers. However, to what reason or reasons should we credit that restraint, and can we reasonably expect this biennial trend to continue more or less the same as the years progress? At this point, one may reason that it is simply too early to tell whether the broadened police powers have been underutilized or whether the statistics presented thus far represent a careful process of undercover operation selection, review and authorization, weeding out those proposals that impart undue risk to the R.C.M.P., fall outside the scope of that which is permissible under the provisions, or would otherwise jeopardize public safety. One may further infer that, as with any new instrument of public policy, and particularly new provisions of the Criminal Code, an initial training period is required to educate those that will put into action those initiatives passed into law by Parliament. It may well be the case that until such time as police services become more accustomed to the powers they indeed have been provided by Parliament, annual reporting statistics will continue to appear modest, to be later followed by a spike in usage once services have truly begun to take advantage of those extended powers. This is, however, speculative and implies all the more reason that a higher degree of rigor be infused by the government and the academic community into the performance measurement and evaluation of anti-organized crime initiatives like the limited criminal liability exemption. This is exactly the type of initiative that Gabor would have incorporated into his analysis had it existed at the time, and is precisely the form of public policy that is in need of strong measures of accountability, risk management and performance evaluation. 
How such an undertaking could be accomplished is examined in the subsequent and final chapter of this paper. Along with providing that examination, the paper will conclude by congregating a number of the pertinent issues raised throughout this paper, namely, the deferential direction provided by the Supreme Court, the scope and breadth of organized crime in Canada as reported by CISC and the arguments put forth by advocates and opponents of the limited criminal liability exemption. The paper will collate these diverse pieces into a collective synthesis of the key issues and attempt to answer the question of whether and how Canadian public legal policy can reconcile the contravention of positive law by its own law enforcement agents in the pursuit of reduced organized crime activity. 


\section{Multiple Dimensions, Multiple Considerations}

This paper has examined in significant detail the socio-legal environment in which the limited criminal liability exemption was conceived and the diversity of perspectives that have contributed to debate surrounding undercover policing. It is clear from this research that organized crime represents a highly diverse amalgam of structures, networks and associations, all of which can be tied together by several common underlying threads, namely their endurance over time and their adaptability to meet new challenges and exploit opportunities as a means to generating material benefits and financial gain.

Clearly, however, more work needs to be done by governments and academics if analyses of organized crime are ever to move past simplistic qualitative anecdotes and highly speculative quantitative guesstimations such that organized crime research becomes more consistently methodologically sound and empirically-based. More particularly, this paper has demonstrated that several key factors contributed to the development and implementation of the limited criminal liability exemption; chief among these factors was the Supreme Court of Canada's ruling in Campbell, which provided a clear indication to Parliament that the highest court in the land was quite prepared to support a more generally applicable criminal liability exemption for police officers than the hodge-podge of exemptions that existed in 1999. Other key factors that contributed to an environment ripe for the introduction of this bold policy measure were the Government of Canada's focus on implementing the National Agenda to Combat Organized Crime and consequent FPT discussions urging jurisdictions to work together to introduce tough legislative and regulatory measures. In addition, public opinion polling conducted for the government around that time helped to reinforce an understanding that the general public was 
becoming restless with the government's perceived lack of progress against organized crime and its appetite for the introduction of tougher measures, even if they came at the public's own expense in the form of reduced civil liberties.

The paper has provided an overview of the scope of organized crime within Canada, utilizing primary data from the Criminal Intelligence Service of Canada. While steering clear of an over-abundant use of speculative dollar estimations, the evidence presented demonstrates the complexity and diversity of issues one must consider when defining organized crime and, further, how so many cross-sections of Canadian society, including the insurance, banking and telecommunications sectors, to street gangs and Aboriginal reserves that straddle the Canada-U.S. border, are affected by this type of criminal behavior. The paper has also examined several of the consequences of undercover policing as categorized by Brodeur. This examination revealed two conclusions. First and most obvious, the complexity of undercover policing defies neatly defined parameters; the outcomes of organized crime investigations entail a host of intended and unintended consequences, some of which are beneficial to law enforcement while others are not. Secondly, owing to this myriad of outcomes, the underlying question that faces policy makers and police leaders is, if bold and decisive measures such as the limited criminal liability exemption are to be put to use, how is it that one can reconcile between the objectives of safer communities and reduced crime with the inherent "evils" of undercover policing and the strong probability that police officers will be put at high risk for situations of misconduct, entrapment and the achievement of particular ends by whatever means necessary? 


\section{Determining Relevance and Effectiveness}

Therefore, with this question in mind, if this paper is to attempt to reconcile the contravention of positive law with the fight against organized crime, a number of overarching questions can and should be extracted from this reconciliation. First, two of the key issues that have resonated throughout this paper and which require a degree of individual examination are the issues of relevance and effectiveness. At this point we need ask ourselves, what has the discussion thus far provided in terms of an indication that the provisions introduced by Parliament demonstrate sufficiently high levels of relevance and effectiveness?

In its ruling in Campbell, the Supreme Court clearly articulated that organized crime is a pressing issue in need of innovative approaches on the part of law enforcement. Taking into account, on the one hand, that situational police illegality is bound to occur on a daily basis and, on the other hand, that structural illegality is a matter to be seriously and necessarily considered on a case-by-case basis, the Court still concluded that the duty and mandate of police services to ensure public safety necessitated some form of criminal liability exemption. The Court pointed out that instances in law already existed in which the police could contravene particular statutes, and further, when this fact was considered in concert with the imperative of police services operating one step ahead of criminal organizations, the Court stated it would be up to Parliament to make a determination that some broader form of criminal liability exemption is necessary. It seems clear from the Court's analysis, at least, the incidence of organized crime clarifies beyond any doubt that a generally applicable criminal liability exemption could be a relevant tool of public policy. However, the Court's deferential attitude stopped short of prescribing the 
boundaries of what such a criminal liability exemption might look like, deferring instead to Parliament to define the parameters of a bold social policy that would most certainly be at odds with those traditionally opposed to the expansion of police powers.

Drawing on public reports from the Criminal Intelligence Service of Canada, it has been demonstrated that a solid working definition of organized crime in Canada is one that incorporates the attributes of persistence, diversity, sophistication and a range of actors actively and opportunistically engaged in violent and destructive activities. These activities range from the theft and export of luxury vehicles, to gang activity and drug trafficking, to insurance and telecommunication fraud. Communities across Canada are implicitly implicated in the activities committed by organized crime, in whatever its collective form, for the simple reason that organized crime is not a vast, faceless conspiracy, but rather a collation of thousands of individual acts of violence and intimidation perpetrated to further the financial and material benefit of the perpetrators. It is selfish and it is destructive. The Government, for its part, publicly recognized the relevance a limited criminal liability exemption during its White Paper process, wherein it directly tied the relationship between the public's best interests to the effective operation of law enforcement in the furtherance of its duties. The Government's introduction into law of a limited criminal liability exemption for police was an unprecedented move and one that clearly indicated that it took seriously the problem of organized crime. Yet, where the discussion falls short, is on the issue of effectiveness. It appears from the research that the Government was in such a hurry to fill the legal and operational void created by the Campbell ruling, that it sacrificed any forethought on how its proposed liability exemption scheme would be evaluated and measured for success. 
Early in this paper, the question was asked whether the limited criminal liability exemption could serve to mitigate the legal and operational difficulties inherent to organized crime investigations and, further, could it increase police effectiveness to those ends. It appears that the answer to that question is that, owing to the absence of a formal performance measurement and evaluation regime, it is still too early to tell. While some minimal inference could be invoked that, owing to the fact that the exemption provisions have been utilized since their introduction, they have therefore provided some aid to law enforcement in the exercise of their duties. Yet no publicly documented analysis exists that can demonstrate the veracity of that inference, let alone the extent to which the provisions have proven effective. For example, it is unclear whether, in the instances cited by the Minister in her two annual reports to Parliament, that the provisions served to minimize the time required to conduct the investigations, and therefore the dollars expended, and whether police officers found the authorization procedures efficient or cumbersome and for what reasons. Nor do we yet know whether the provisions actually enhanced the safety of police officers since if, in theory, they were able to receive approval to commit certain illegal activities and were therefore better able to "mix-in" with the criminal organizations, they were better able to play the role they needed to play during undercover operations. Once again, what this speaks to is the lack of publicly available research that focuses specifically on a particular organized crime control strategy from the point of introduction to a specified point of evaluation and reflection.

While more global statistical data on the occurrence of organized crime will begin to appear during the fiscal year 2005-06 through the UCR2 survey administered by Statistics Canada, the exclusively statistical nature of the Minister's reports to Parliament 
on the use of the limited criminal liability exemption provisions, albeit including a short description of the suspected crime for which they were invoked, provide little in the way of continued reassurance to the public that their utilization is effective in the sense that their invocation has directly contributed to a reduction in organized crime. Perhaps, however, that is too simplistic a causal connection, and therefore what needs to be developed is a more rigorous methodology for measuring the performance of the exemption provisions. The annual reports to Parliament, as they are currently structured, provide little in the way of public accountability since there is no public demonstration that the government has linked their invocation to a serious attempt to measure performance and answer - in some reasonable form - whether and how this particular strategy is contributing to a reduction in organized crime.

It is simply not enough to rest on the accountability regime that already exists within the liability provisions, which dictates only how the provisions are to be utilized and by whom and under what circumstances they are engaged. A broader understanding of accountability is needed if we are to do justice to the provisions in the long-term, a key component of which will be the forthrightness on the part of the government to state publicly how it defines organized crime, how often it has used the provisions, under what circumstances and, cumulatively, how have the provisions aided law enforcement to make their job easier? More effective? More efficient? And is it possible to quantify in some form of cost-benefit analysis what the alternative would have been had the limited criminal liability provisions not been invoked (e.g., longer investigation period, increased risk of harm to the officer, loss of evidence, probable loss of convictions, etc)? 
These may seem like obvious questions, but they are at the heart of the matter and speak directly to why the provisions were introduced in the first place. If there is no determination of the benefit of a particular policy, why continue with it? It is precisely because of the danger, secrecy and inherent difficulties associated with organized crime investigations that demands a high standard of public reporting and, within reason, transparency if the provisions are to remain on the books.

\section{Determining Measures of Accountability}

If it is reasonable to expect a higher standard in the realm of performance measurement and evaluation, it is also implicit these measures contribute to a higher standard of accountability. Gabor cautioned readers about the lack of consensus on the definition of organized crime, the inherent difficulties associated with data collection issues and the use of crude and varied performance measurement indicators. In all likelihood, the introduction of an agreed-upon definition of organized crime among FPT jurisdictions will solve the first of Gabor's dilemmas, however, progress may be stymied on the second and third issues if significant coordination among governments is not achieved. It would be a major step forward if FPT jurisdictions agreed upon a collective approach to not only the legislative reporting of the criminal liability exemption provisions, but also a long-term latitudinal survey of its effectiveness and impact on organized crime. To not undertake such an approach would be to confine ourselves to a continued reliance upon strictly anecdotal information absent the research-based rigor that should underlay good public policy. While there will be obvious limitations within which such a study could operate given the sensitive nature of the data involved, a meta-analysis 
that globally "rolls-up" jurisdictional information concerning such issues as police officer training, implementation, frequency, usage and operational challenges associated with the exemption provisions would be inherently beneficial to both police services and legislators.

The ultimate goal of investing in a research component to the limited criminal liability exemption scheme is one of accountable public policy. The bold and sensitive nature of these Criminal Code provisions requires a correspondingly bold and sensitive accountability regime that serves to justify their continued place in statutory law and further demonstrates on a reasonable and periodic basis measurable effectiveness in achieving results against organized crime. An integral part of what this research must address is how jurisdictions reach a common understanding of what constitutes "reasonable and proportional" within the context of the exemption's justification section.

\section{What Is Reasonable and Proportional?}

If there is a particular section within the limited criminal liability exemption provision that potentially stands out for legal challenge more than any other, it is the third tenet of the justification provision. It is within this section that the officer must demonstrate to the competent authority that, based on reasonable grounds, the proposed act or omission is reasonable and proportional in the circumstances, giving weight to factors such as the nature of the investigation and the availability of other means for carrying out the officer's law enforcement duties. The reason that this section stands out as compared to other sections within the provision is a simple matter of interpretation. As compared to, for example, the other two tenets of the justification provision which call for 
a mere demonstration of fact (i.e., that the officer is engaged in an investigation of an offence and that the officer is designated by a competent authority), the reasonable and proportional clause asks the competent authority to make a judgment call - albeit likely based on legal advice - as to whether the proposed illegal activities can be justified within the circumstances. And while it should not be the role of the courts to continually second-guess the decisions made by competent authorities, which after all should be "competent" enough in the sphere of criminal investigations to weigh the prescribed parameters outlined in the liability provision, there is a need for a national, clearly articulated framework on undercover policing to provide further direction on the matter.

A national framework, endorsed by FPT jurisdictions, would serve to outline the general operational and policy parameters around which jurisdictions agree to operationalize, monitor and evaluate the limited criminal liability exemption provisions in particular, and engage in undercover policing operations more generally. The framework would serve to achieve consensus among jurisdictions about the essential procedural and authorizational elements required in undercover policing guidelines, but which would continue to be developed and tailored at the local level and remain specific to each police service. What police services would then have in common is an over-arching agreement on the common denominators integral to those guidelines and the balance that should be struck between procedural elements and authorizational elements. However, the major impediment one could anticipate in reaching such national consensus is of course the fact that policing in Canada is primarily a provincial jurisdiction. Short of an initial consensus among provinces to work toward such a scenario, there is little that the federal government could do by way of its constitutional responsibilities to initiate such a project. 
Another way to look at the situation is if the federal government, through the Minister of Public Safety and Emergency Preparedness, took it upon itself to provide appropriate direction to the national police force to develop a public set of undercover policing guidelines, comparable to those utilized by the FBI, but tailored to the Canadian context, and which could then be replicated by provincial, municipal and Aboriginal jurisdictions. Such direction could potentially be achieved through the Minister's annual mandate letters $^{70}$ to the Heads of Portfolio Agencies, which set the expected direction of each agency reporting to the Minister.

The benefit of elevating the limited criminal liability exemption provisions from a stand-alone provision within the Criminal Code to being set within the broader context of national guidelines for undercover policing is primarily one of transparency and accountability. The implementation of publicly available guidelines would demonstrate a willingness on the part of police services to reduce the risk of those undesirable and unintentional consequences of undercover policing that were outlined earlier in this paper and have been examined in far greater depth and detail by others. A balance between operational confidentiality and public transparency is possible, and yet it can be achieved only if jurisdictions are serious about removing the unnecessary elements of secrecy inherent to undercover policing - those elements that minimize or preclude measurable

\footnotetext{
${ }^{70}$ Mandate letters are annual call letters by the Minister of Public Safety and Emergency Preparedness to the Heads of each of the Agencies that fall within the Portfolio of Public Safety and Emergency Preparedness (i.e. the Commissioner of the R.C.M.P., the Commissioner of the Correctional Service of Canada, the President of the Canada Border Services Agency, the Commissioner of the Canada Firearms Centre, etc). Pursuant to the Department of Public Safety and Emergency Preparedness Act, the Minister is authorized to establish strategic priorities for the entities that fall within his/her responsibility. One such avenue available to the Minister is the provision of an annual Mandate Letter that sets out the Minister's expected strategic priorities for that particular agency.
} 
results and performance indicators, transparent operational guidelines and methodologically rigorous research and development activities.

\section{Future Directions}

This paper initially set out to examine a relatively new piece of public policy, seeking to answer whether an innovative and bold, but highly sensitive, policy could be justified in light of the circumstances in which it was introduced and in light of the conditions that continue to persist in the investigation of organized crime. At the heart of the matter is an inherent tension between the expansion of police powers, based upon a highly complex but nebulous phenomenon known as organized crime, and a seemingly contradictory goal to reduce crime through the commission of illegal acts or omissions on the part of the police. What this paper has attempted to demonstrate is that this tension is not necessarily unhealthy, but that greater clarity and rigor needs to be brought to bear on this debate.

It is clear that the limited criminal liability exemption is a timely and relevant public policy, directly attributable to a long series of other policy precursors and social conditions, all of which combined at a period in time to produce an environment that was conducive to a bold step forward in legal policy. According to the research, the incidence of organized crime in Canada and the deviant, manipulative means utilized to further its ends present the distinct conclusion that this problem will continue to threaten the stability of communities. The challenge for policy makers will be to equip police services with strategies and tactics considered reasonable and proportional in order to counter its occurrence. While one may choose to deem it unfortunate, the very definition of "reasonable and proportional" in this case is one that calls for police services to be vested 
with the legal authority to commit illegal acts or omissions in the course of organized crime investigations. This is the nature of the problem that Canada and other nations must deal with and, while it may be unpalatable to some that the very institutions dedicated to upholding the law are being called upon to contravene that law, the crux of the issue is one of necessity and a determination to uphold the rule of law through means that are proportional and demonstrably effective.

The problem of organized crime in Canada calls for an affirmation that governments approach the issue with intelligent policy choices, such as the limited criminal liability exemption, but yet also be required to further demonstrate to the highest degree possible in the public sphere that their efforts are being implemented within the confines of the constitution, are achieving measurable results and are exercised in a highly rigorous framework of accountability. This is not yet the case with the limited criminal liability exemption. Its introduction into the Criminal Code was only the first of several necessary steps. What is now required is a further articulation by the government on how it intends to improve the performance measurement and evaluative component of these provisions, along with the development of an enhanced accountability framework inclusive of guidelines for undercover policing in Canada that can be replicated across jurisdictions.

The introduction of the limited criminal liability exemption provision was a positive policy direction, yet it cannot be left to languish in a void that so desperately needs to be filled by good research, a national regulatory framework and stronger measures of accountability, since to do otherwise would be tantamount to repeating the mistakes of the past. Understanding our progress against organized crime through solid 
research, transparent accountability and strong government leadership should be a cornerstone of any future policy direction. The time is now right for a second phase in the life of these provisions and it calls for a more comprehensive and integrated approach. 


\section{References}

Auditor General of Canada, Report of the Auditor General of Canada to the House of Commons: April 2002 (Ottawa: Auditor General of Canada, 2002)

Beals, Lalonde \& Associates, "Report of the Delphi Panel on Operational Definition of Organized Crime” (October 2002) [unpublished].

Beare, Margaret, Criminal Conspiracies: Organized Crime in Canada (Toronto: Nelson House, 1996) at 138.

Beare, Margaret, "Facts From Fiction - Tactics and Strategies of Addressing Organized Crime and Organized Criminals" (Canadian Police College Seminar Series: Perspectives on Organized Crime in Canada, Canadian Police College, 21 June 2000) (2000) [On-line] Available: http://www.yorku.ca/nathanson/Publications/facts.htm

Beare, Margaret, “Structures, Strategies and Tactics of Transnational Criminal Organizations: Critical Issues for Enforcement" (Australian Institute of Criminology, Australian Customs Service and Australian Federal Police Transnational Crime Conference, 9-10 June 2000) (2000) [On-line] Available:

http://www.yorku.ca/nathanson/Publications/aust.htm

Beare, Margaret and Juan Ronderos, "Exploratory Review of Media Coverage on Organized Crime in Canada: 1995-2000” (2001) [On-line] Available:

http://www.yorku.ca/nathanson/Publications/nathanson.htm

Bill C-24, An Act to amend the Criminal Code (organized crime and law enforcement) $1^{\text {st }}$ Sess., $37^{\text {th }}$ Parl., 2001, el.2 (assented to 18 December 2001).

Brauti, Peter and Candice Welsh, "Illegal Police Conduct in the Course of a Bona Fide Investigation" (1999) 43 Criminal Law Quarterly, 64.

Brodeur, Jean-Paul, "Undercover Policing in Canada: A Study of Its Consequences" in Cyrille Fijnaut and Gary T. Marx, eds. Undercover: Police Surveillance in Comparative Perspective, The Hague (The Netherlands): Kluwer Law International. 1995, x, 337. A1-A2.

Bronskill, Jim, “Court handcuffs police: RCMP” Ottawa Citizen (12 March 2001) A1-A2.

Bronskill, Jim, "Even police wary of new powers" Ottawa Citizen (11 April 2001)

Bueckert, Dennis, "Duceppe accepts RCMP protection” Ottawa Citizen October 2000) 
Cobb, Chris, "Bill's critics fear police 'dirty tricks"” Ottawa Citizen (6 April 2001) A1-A2.

Cohen, Stanley, "The Investigation of Offences and Police Powers" (1981) 13:3 Ottawa Law Review, 549.

Consulting and Audit Canada, Development of Data on Organized Crime: Draft Report (Ottawa: Consulting and Audit Canada, 2002).

Criminal Intelligence Service of Canada, 2004 Annual Report: Organized Crime in Canada (2004) [On-line] Available: http://www.cisc.gc.ca/annual_report2004.htm

Criminal Intelligence Service of Canada, 2005 Annual Report: Organized Crime in Canada (2005) [On-line] Available: http://www.cisc/gc.ca/annual_report2005.htm

Dubois, Judith, "Media Coverage of Organized Crime: Impact on Public Opinion?" (2002) Royal Canadian Mounted Police [On-line] Available: http://www.rcmp-grc.gc.ca

Gabor, Thomas, "Assessing the Effectiveness of Organized Crime Control Strategies: A Review of the Literature" (2003) Justice Canada [On-line] Available: http://www.justice.gc.ca/en/ps/rs/rep/2005/rro5-5/index.html

Gold, Alan D., "Controlling the Work of the Police" (Lecture, Canadian Institute for the Administration of Justice, Conference on the Judiciary as Third Branch of Government: "Manifestations and Challenges to Legitimacy" 16 October 1999) (1999) [On-line] Available: http://www.ciaj-icaj.ca/english/publications/1999/Gold-99.pdf

Hamilton, Henry and John Ortiz Smykia, "Guidelines for Undercover Police Work: New Questions About Accreditation and the Emphasis of Procedure over Authorization" Justice Quarterly, Vol. 11, No. 1, March 1994, 144-145.

Ipsos-Reid, "Public Views on Organized Crime" Justice Canada (2001)

Justice Canada, Available statistics on the national policy priorities and emerging issues identified in the National Agenda to Combat Organized Crime by Mylène Lambert (Ottawa: Justice Canada, 2002)

Justice Canada, Government Steps Up Fight Against Organized Crime (2001) [On-line] Available: http://www.canada.justice.gc.ca/en/news/nr/2001/doc 26096.html

Justice Canada, Royal Assent of Bill C-24 Organized Crime Legislation (2002) [On-line] Available: http://www.canada.justice.gc.ca/en/news/nr/2001/doc_28213.html

Justice Canada, Law Enforcement and Criminality White Paper (2000) [On-line] Available: $\underline{\text { http://www.canada/justice/gc/ca/en/cons/lect.html }}$ 
Morgan, Elaine, "Police Immunity, Public Policy and Proportionality" (1999) New Law Journal, 13.

Perka v. The Queen [1984] 2 S.C.R. 232.

Pheonix Strategic Perspectives, "Canadian's Views on Organized Crime: Final Report on the Findings of a Qualitative Study" (July 2005) [unpublished: archived at Public Safety and Emergency Preparedness Canada]

PhoneBusters, "Identity Theft Complaints" (2003) [On-line] Available: http://www.phonebusters.com/english/statistics_EO3.htm

Porteous, Samuel D., “Organized Crime Impact Study: Highlights” (1998) [On-line] Available: http://ww2.psepcsppcc.gc.ca/Publications/Policing/1998orgcrim e.asp

Public Safety and Emergency Preparedness Canada, Working Together to Combat Organized Crime: A Public Report on Actions Under the National Agenda to Combat Organized Crime (2004) [On-line] Available: http://www.psepcsppcc.gc.ca/publications/policing/combat_org_crime_e.asp

Public Safety and Emergency Preparedness Canada, Annual Report on the Law Enforcement Justification Provisions Pursuant to Section 25.3 of the Criminal Code: 2002 (2002) [On-line] Available: http://www.psepc.gc.ca/publications/policing/20030611 e.asp

Public Safety and Emergency Preparedness Canada, Annual Report of the Law Enforcement Justification Provisions: 2003 (2003) [On-line] Available: http://www.psepc.gc.ca/publications/policing/lawenforce04_e.asp

Public Safety and Emergency Preparedness Canada, Annual Statement on Organized Crime (1998) [On-line] Available: http:ww2.psepcsppcc.gc.ca/Publications/Policing/pdf/199812orgcrime_e.pdf

Reany, Gail M., "Crossing the Constitutional Line: Due Process and the Law Enforcement Justification" (1999) 67 Notre Dame Law Review, 745.

Roberts, Julian, "Fear of Crime and Attitudes to Criminal Justice in Canada: A Review of Recent Trends 2001-2002" (2001) Public Safety and Emergency Preparedness Canada [On-line] Available: http://www.psepcsppcc.gc.ca/publications/corrections/FearOfCrime_e.asp\#Executive

Rothman v. R., [1981] 59 C.C.C. (2d) 30 at 74.

Royal Canadian Mounted Police, Report on Plans and Priorities: 2001-2002 [On-line] Available: http://www.rcmp-grc.gc.ca/dpr/rpp2001 e.htm 
R. v. Bond [1993] 135 A.R. 329

R. v. Campbell [1999] 1 R.C.S. 577

R. v. Matthiessen [1995] 134 C.C.C. (3d) vi (S.C.C.)

R. v. Mack [1988] 2 S.C.R. 903

R. v. Lore [1997] 132 C.C.C. (3d) vi (S.C.C.)

Statistics Canada, Organized Crime in Canada: An Investigation into the Feasibility of Collecting Police-Level Data by Lucie Ogrodnik. (Ottawa: Statistics Canada, 2002).

Statistics Canada, Organized Crime Activity in Canada, 1998: Results of a "Pilot" Survey of 16 Police Services by Julie Sauvé. (Ottawa: Statistics Canada, 1999).

Stober, Michael, "The Limits of Police Provocation in Canada (1992) 34 Criminal Law Quarterly. 290.

United Nations Convention against Transnational Organized Crime, GA Res. 55/25, UN GAOR, 55 ${ }^{\text {th }}$ Sess., UN Doc. A/RES/55/25 (2001) 4.

U.S. Department of Justice, “Attorney General's Guidelines on FBI Undercover Operations: Revised 11/13/92" (1992) [On-line] Available:

http://www.usdoj.gov/ag/readingroom/undercover.htm 